\title{
La formación del sistema agrario colonial en Piura. Anotaciones sobre la ciudad de San Miguel y el nacimiento de la hacienda Tangarará, siglos XVI-XVII
}

Artículos originales: SOCIOLOGÍA

Recibido: $14 / 08 / 2020$

Aprobado: 13/10/2020

Publicado: 05/02/2021
César Espinoza Claudio

Universidad Nacional Mayor de San Marcos

cespinozac@unmsm.edu.pe

\begin{abstract}
RESUMEN
En este ensayo buscamos presentar algunas ideas y el registro de datos compilados en los archivos de Piura y Lima sobre como la economía de Piura entre 1532 y 1650 va a sufrir un giro socioeconómico de tránsito de la agricultura a la economía estanciera, una dinámica histórica que estará acompañada de una explicación sobre el movimiento de la ciudad de San Miguel de Piura, la utilización del peonaje asalariado y el colonato campesino indígenas y el trabajo de los negros esclavos y libertos, y los procesos de concentración de la tierra que posibilitaran la formación de un sistema agrario colonial en el corregimiento y provincia de Piura. Esta estructura agraria virreinal empieza primero a construirse con la organización y distribución de la tierra a los pueblos y comunidades indígenas que despliega el virrey Francisco de Toledo desde 1572 para luego estabilizar el corregimiento de Piura con la refundación de la ciudad en 1588 por el virrey Conde del Villar, en el sitio actual, y proseguir con el proceso de privatización de las tierras circundantes y a organizar en un segundo momento las haciendas y las estancias ganaderas entre la ciudad y el territorio ubicado al pie de la cordillera de los Andes en el siglo XVII. Finalmente, exploramos algunas variables sobre el proceso de formación y consolidación de la hacienda de Tangarará y sus pugnas con el Estado virreinal revisando documentos notariales y expedientes civiles.
\end{abstract}

Palabras Clave: Hacienda; Tangarará; Piura; tierras; ciudad.

\section{Formation of the colonial agrarian system in Piura. Notes about the city of San Miguel and the birth of hacienda Tangarará, 16th-17th centuries}

\begin{abstract}
In this essay, we present some ideas and data records compiled in Piura and Lima archives about how the economy of Piura between 1532 and 1650 will undergo a socioeconomic shift from agriculture to farming. This historical dynamic accompanied by an explanation about the movement of the city of San Miguel de Piura; the use of salaried peonage, the colonization of indigenous peasants, and the labor of black slaves and freedmen; which will make possible the formation of a colonial agrarian system in the 'corregimiento' and province of Piura. In this case, the first stage of the viceregal agrarian structure begins to be built with the organization and distribution of land to indigenous peoples and communities that Viceroy Francisco de Toledo deploys since 1572, to later stabilize the 'corregimiento' of Piura with the refounding of the city in 1588 by Viceroy Conde del Villar in its current location. The second stage continues with the privatization process of the surrounding lands to promote haciendas and cattle ranches between the city and the territory located at the foot of the Andes mountain range in the seventeenth century. Finally, we explore some variables on the process of formation and consolidation of hacienda Tangarará and its struggles with the viceregal State, reviewing notarial documents and civil files.
\end{abstract}

KeYwords: Hacienda; Tangarará; Piura; lands; city.

1 Este articulo forma parte del Informe del proyecto de investigación 2019: PSINFINV Código: E19150032. Nº5981-R-19. Título: Tierras y señores, jerarquías y redes de poder en el valle de La Chira, Piura. Un examen preliminar de la hacienda de Tangarará: 1532-1845. GI. Afrodescendientes en Piura. 


\section{Anotaciones sobre la gran propiedad de la tierra: la hacienda y la estancia}

E n Piura la historia agraria está prácticamente estancada y muy poco es lo que se ha publicado en estas primeras dos décadas del siglo XXI examinando sus cambios y permanencias. La novedad de nuestro tiempo es que nuevamente está surgiendo la gran propiedad y se va organizando un sistema de extensas propiedades o haciendas acompańadas de una vasta red de pequeñas y medianas propiedades rurales orientadas a un nuevo tipo de organización de la agroexportación ahora representada por la producción y comercialización del banano orgánico, el mango, el limón, la uva de mesa, la palta y otras plantas tropicales que demanda el mercado internacional habiendo casi desaparecido el algodón.

En el valle de La Chira se ha incrustado ahora el cultivo de la caña de azúcar y el arroz explotando el agua que disponen de Poechos. De igual forma en el valle de San Lorenzo y las Lomas se cultiva el arroz y los frutales usando una densa red de canales con escasas cantidades de agua. La novedad de este siglo es que el mayor volumen de agua se concentra en la represa de Poechos que sirve para el riego de miles de hectáreas de los cultivos agrofrutales pero también para el consumo humano. En ambos valles la superficie territorial esta cruzada por múltiples canales de agua que transportan toneladas de este recurso hídrico que van a cruzar Tambogrande y a desembocar en las lagunas circunvecinas a Sechura, y al otro lado de Payta, en las playas de San Lucas de Colán luego de usarlas en ambas orillas del rio de La Chira. Así, luego de las inundaciones y el diluvio de marzo del 2017 ahora se vive un tiempo de años secos y de programas y conferencias de cómo solucionar el impacto de las alteraciones climática en un tipo de agricultura comercial que está azotada por la pandemia del Covid-19. ${ }^{2}$

2 Véase el contenido de la Conferencia internacional ONLINE Piura Morfología fluvial Control de Inundaciones 2020 https://www.iahr. org/en/lives/details?live_id=30 Consultado el 02.12.2020. Para una mayor visión de lo que ocurre con el agro de Piura se puede consultar los informes en https://www.vigiliaciudadana.org.pe/informeespecial/el-peihap-se-equivoca-en-nulidad-de-contrato-consorcioespanol-y-perjudica. El PEIHAP se equivoca en nulidad de contrato a consorcio espańol y perjudica gravemente a Piura; 21.02.2019. Otras lecturas sobre lluvias e inundaciones en Eduardo Franco Temple 1991 y 2002; Carolina Diaz Maldonado 2013 y Cristina Vargas 2017.
Este proceso de reconcentración de la tierra no ha llamado la atención de los historiadores de San Marcos como si ocurrió en los 70s del siglo XX en la que una generación liderada por Pablo Macera, Aracelio Castillo, Matos Mar y Humberto Rodríguez Pastor impulsaron varias investigaciones y libros que mostraban como el sistema de hacienda se había organizado y hegemonizado no solo la vida agraria sino también la vida política regional y nacional. En esa ocasión se asociaron los conflictos y las revueltas agrarias con la necesidad de estudiar a la gran propiedad rural y evaluar el desarrollo agrario y sus tendencias en la larga duración. ${ }^{3}$

Posteriormente va a ser el CIPCA quien lidere el estudio del agro y el campesinado en Piura, una actividad que estará asociado a los trabajos de investigación que realiza un convenio franco-alemán en la que sus investigadores buscan profundizar la conexión territorial y humana de la sierra de Piura con la cordillera y poblaciones de Loja y Cuenca. Producto de estos esfuerzos académicos de reconstruir la base agraria y regional de Piura destacan los libros de Anne Marie-Hocquenghen, Alejandro Diez Hurtado, Susana Aldana Rivera, que son la continuación de los avances logrados por Eduardo Franco Temple, Bruno Revesz Long y Jacobo Cruz Villegas. La preparación y difusión de "Piura: región y sociedad. Derrotero bibliográfico para el desarrollo" y el funcionamiento de un centro de documentación regional (CEDIRCIPCA) ayudaron a que Piura ingrese al debate y a la construcción de conocimientos sobre la temática agraria y la propuesta de alternativas de desarrollo rural y agrario. En esta experiencia personal destaca el trabajo académico de Bruno Revesz quien desde el estudio de caso sobre Catacaos transitó a la escritura y a la reflexión de la pequeña agricultura comercial, el desarrollo rural en la sierra y la minería y el conflicto social contemporáneo (Bruno Revesz et al 1997 y Anne Marie Hocquenghen 2004).

En estos últimos ańos se registra la novedad del ingreso de la Universidad de Piura (UDEP), la Universidad Nacional de Piura y la Pontificia

3 Aracelio Castillo Cruz y Zenón Vargas Morales. 1977. El Imperialismo y la naturaleza de su incidencia en la historia del agro en el valle del Alto Piura. UNMSM, Lima, Perú. Bernardino Ramírez; César Espinoza; Marika López y Carmen Torres. 1982. El problema agrario en el valle de la Chira, Piura, UNMSM, Lima, Perú. 
Universidad Católica del Perú al estudio de los temas sociales vinculados a la historia agraria y política abarcando los siglos XVI y XXI, organizando y formando un equipo humano de investigadores que han explorado el Archivo Regional de Piura, el Archivo General de la Nación y muchos archivos del mundo para ofrecer varias de líneas de investigación de naturaleza interdisciplinaria. ${ }^{4}$

Los estudios que ahora difunden por la vía digital combinan y sistematizan lo que se ha podido explorarse por muchos estudiosos locales, pero también de profesionales procedentes de otras ciudades del Perú y del mundo. La organización de eventos y la difusión de las tesis y trabajos de investigación histórica han permitido el surgimiento de nuevas propuestas sobre las estructuras y los actores que dinamizaron la vida regional y de cómo se enfrentaron al desafío de impulsar el desarrollo económico y político de una región marginada durante el tiempo de los Borbones y el siglo XIX republicano (Pablo Luna 2013: 1-8).5

Faltan estudios sobe el surgimiento del latifundio en Piura. Entre los siglos XVI y XVIII se formaron Tangarará y Tambogrande en el valle de La Chira, pero también Morropón y Yapatera al pie de la cordillera de los Andes. Estas grandes propiedades rurales concentran la mano de obra indígena y afrodescendiente en momentos de una depresión demográfica, acompañado de un ciclo preliminar de negocios algodoneros y ganaderos que explosionará con la negociación agrícola Pabur en la segunda mitad del siglo XX. ${ }^{6}$

En este ensayo buscamos presentar algunas ideas y fuentes consultadas en los archivos de Piura y Lima sobre como la economía de Piura sufrió un giro económico de la agricultura a la economía estanciera, una dinámica histórica que estará acompañada de una explicación del movimiento de la ciudad de San Miguel de Piura, la utilización del peonaje asalariado y el colonato campesino indígenas y el trabajo de los negros esclavos y libertos, anudando una econo-

4 Puede consultarse Alejandro Diez 2017; María Luisa Burneo 2016; Alejandra Huamán Tejo 2017; y María Luisa Burneo y Alejandra Huamán 2013.

5 A modo de ejemplo puede consultarse los trabajos de investigación de Laura Albornoz Neyra 2015; Ruth Rosas Navarro 2013 y 2019; Carmen Velasco Seminario 2014. Jorge Elías Lequernaqué 2004; Violenta Sir Jiménez 2019.

6 Aracelio Castillo Cruz y Zenón Vargas Morales,1977. Sobre la crisis agraria en el valle del Alto Piura. En: Revista Estudios N³, UNMSM, pp. 9-51, Lima, Perú. mía estanciera al movimiento portuario de Paita y a la demanda de la economía de Lambayeque-Saña (Lorenzo Huertas 2009 y 1991: 489-500; Susan Ramírez 1985: 251-279 y 2002: 831-840).

La estructura agraria virreinal empieza primero a construirse con la organización y distribución de la tierra a los pueblos y comunidades indígenas que despliega el virrey Francisco de Toledo desde 1572 para luego estabilizar el corregimiento de Piura con la refundación de la ciudad en 1588 por el virrey Conde del Villar, en el sitio actual, y proseguir con el proceso de privatización de los tierras circundantes y formar en un segundo momento las haciendas y las estancias ganaderas entre la ciudad y el territorio ubicado al pie de la cordillera de los Andes. Este proceso político permitirá entonces la formación y consolidación del sistema de hacienda en el siglo XVII desde el Estado virreinal utilizando las reales cedulas que ordenan las visitas, revisitas, composiciones y mensuras de las tierras de los ańos de 1595, 1645 y 1714, movilizando para esto a grupos y comisiones de funcionarios civiles y militares que van a lanzar pregones, revisar los documentos notariales y a negociar con los dueños de la tierra para ajustar las tasas de pago que debían cancelar en moneda de plata de ocho o nueve reales.

Entre 1532 y 1588, la gente que llegó con Pizarro y los nuevos virreyes van a trasladarse a varias pequeñas urbes que se levantaron bajo la categoría de bases políticos y militares porque Piura es la entrada y salida de las tropas y armas que sirven para colonizar los Andes, pero también para que Payta cumpla su misión de unirse con Panamá por el norte y la ciudad de Lima por el sur. Los virreyes necesitan de una urbe que permita controlar las ciudades circunvecinas (Loja, Quito y Saña) (Georg Petersen 1962: 359-383; Juan José Vega 1993; Raúl Estuardo Cornejo: 2007: 155-163; Esteban Mira Caballos 2007: 82-153).

Pizarro funda y puebla San Miguel de Nueva Castilla (Tangarará) en 1532 para luego la tropa y los indígenas de apoyo militar trasladarse al valle de Piura, al cerro de "El Pilan", cerca de Moscalá, en la que Diego de Almagro construyó las bases de un nuevo centro poblado que permanecerá en este sitio medio siglo y será conocido como San Miguel de Piura. Aquí empiezan a funcionar las primeras unidades rurales bajo la forma de tierras o sitios de hacienda para producir, maíz, cebada, trigo y cańa de azúcar. El acelerado proceso de despoblación indígena im- 
pedirá que este valle y la ciudad pueda desarrollarse. La guerra entre los encomenderos y luego contra el rey de España destroza la base material de los vecinos que se asientan en este espacio de abundantes tierras de labranza y de una densa red de canales y acequias que aseguraban la disponibilidad del agua. De igual forma, los caminos, puentes y tambos existentes permitirán asegurar en este ciclo histórico la comunicación fluida con la gente de la sierra y los pueblos de Olmos, Motupe y Saña (Néstor Martos 1958: 158166; Reynaldo Moya 1994.).

El FEN de 1578 fue tan poderoso y destructivo que los obligo a mudarse prácticamente a la bahía de Payta pues el diluvio, los huaicos, las tormentas de aguas incontenibles provocaron la presencia de muchas epidemias y enfermedades tropicales. El grupo de encomenderos y de vecinos sobrevivientes se asientan en este pueblo de pescadores bajo el nombre de San Francisco de la Buena Esperanza de Paita, allí permanecerán y aumentará el número de vecinos y también de los negocios hasta que de manera imprevista se presentó a finales de 1587 el corsario Thomas Cavendisch quien destruyó y asaltó la ciudad, la iglesia y los depósitos de los comerciantes locales. La población blanca pudo subir al tablazo desértico y refugiarse en los centros poblados de Catacaos y Colán.

Transcurrido un año de gestiones de los vecinos y las autoridades, el virrey Conde del Villar autorizó la refundación de una nueva ciudad en el sitio "El Chilcal", frente al pueblo de El Tacalá, en tierras de los Catacaos, bajo el nombre de San Miguel del Villar, para luego de transcurrido un poco el tiempo asumir el nombre de San Miguel de Piura en 1588 (Juan Paz 1986 y Demetrio Ramos: 1972).

Pocos años después, la formación de la gran propiedad rural estará vinculada a la historia de esta pequeña urbe que se convierte en la sede y capital del corregimiento de Piura y sus vecinos estarán vinculados al obispado de Quito hasta 1616. Esta es la base de la causalidad que se propone como hipótesis de trabajo, pues los vecinos que se asientan en este lugar dispondrán temporalmente de un Cabildo de Españoles que administran las tierras de «Ejidos» ubicados en los llamados «extramuros» de la ciudad. Posteriormente, la privatización de las tierras realengas empezará por espacios territoriales circunvecinos a esta ciudad y emergerán Terela, Chapallirá y la hacienda de Tambogrande y más arriba Malingas. Esta es la hipótesis que se plantea trabajar sobre los orígenes y el inicial desarrollo de la hacienda y luego de la estancia ganadera.

La hacienda es una propiedad rural que la administran en la primera mitad del siglo XVI los familiares vinculados a los encomenderos y también a los vecinos que han comprado un pedazo de tierras, ligado al sistema de autoridades del Cabildo y que utiliza una variedad de sistemas laborales para explotar la tierra y el agua, para esto disponen de grupos de mitayos, de peones asalariados, y la producción agrícola y pecuaria la dirigen a un mercado local pero también a Saña, Lambayeque y Panamá. En la segunda mitad del siglo XVI se organizan "compañías" ganaderas entre vecinos españoles que buscan la acumulación del capital para luego utilizarlos en una diversidad de negocios que llegan desde la compra de ropa de Castilla hasta la venta de negros esclavos. Un encomendero asignado a Sechura como López de Ureña se dedicó a la crianza de ganado caprino, a la compra de tierras $\mathrm{y}$ al negocio de la venta de ropa europea en la ciudad de Panamá y España. ${ }^{7}$

Es muy poco lo que reinvierte en Piura. Ureña es un clásico ejemplo de cómo se transita de la encomienda a dueño de la tierra bajo la forma de hacienda o estancia. Busca acumular cantidades de dinero en moneda plata para asegurar la continuidad de su estatus social y trasladarlo hacia otra ciudad o región. En suma, en este caso la producción de la hacienda ganadera está orientada a un mercado mayor que se ubica en Saña y Lambayeque. La tierra y la encomienda les permitirán también a algunos descendientes de los conquistadores a gozar de la categoría de corregidores y otras mercedes reales.

Varios estudios han planteado ya que la encomienda no implica tener derechos sobre las tierras de los indios; el rey de España le otorga la encomienda a los conquistadores y sus familiares para que goce de un repartimiento de indios que en adelante están obligados a pagar un tributo y otros servicios personales. La evidencia documental que presentamos muestra que la encomienda si estaba vinculada al

$7 \quad$ AGI Lima, 2010, N.3. 1593. Informaciones de Alonso Forero de Ureńa: capitán, corregidor de San Miguel de Piura, Cuenca, Loja, Zamora, Jaén y Paita; abrió caminos, pobló y formó San Andrés de Ureńa, hizo la presa del río llamada el Tacala, etc. Información y parecer de la Audiencia de Lima. 
proceso de privatización de las tierras realengas, pero también de los pueblos y las comunidades indígenas.

En Piura si existió una conexión cercana entre la encomienda y el sistema de hacienda. En Sechura, Catacaos y Colán a los encomenderos las autoridades municipales le otorgan pedazos y sitios de tierra que después sus familiares van expandiendo y en las comisiones y visitas reales obtienen finalmente un registro o el titulo firmado por las autoridades de las "composiciones", a cambio de la entrega de una cantidad de moneda plata.

Los encomenderos casi no se encuentran en la pequeña urbe de Piura que sobrevive a un costado del rio; por el contrario, los hacendados si residen temporalmente en el campo, en sus casas-haciendas para vigilar el trabajo de los mayordomos y caporales. Conforme avanza el siglo XVII el problema creciente es la disminución radical de la mano de obra indígena y empieza ya a registrarse la presencia permanente de negros y negras que son utilizados en los trapiches y molinos de la caña de azúcar y el tráfico mercantil.

\section{La subordinación de la urbe de Piura a la sociedad indígena tallán a finales del siglo XVI}

Entre 1532 y 1595, la información sobre la instalación de los primeros espańoles en los centros poblados de San Miguel de la Nueva Castilla (conocida como San Miguel de Tangarará), San Miguel de Piura (Piura La Vieja), San Francisco de la Buena Esperanza de Paita y San Miguel del Villar (San Miguel de Piura), y la posesión del oro y la plata recibida en los repartos y Cajamarca, y la utilización de estas fortunas en la compra de tierras y los negocios ganaderos son muy escasos y dispersos en la bibliografía publicada en el Perú y el mundo. Las crónicas de la Conquista solo ofrecen una información parcial e interesada y es muy poca la información trabajada por los historiadores acerca del impacto de la guerra de conquista de Pizarro y el proceso de formación de una nueva administración territorial de la etnia tallan y de poblaciones forasteras que encontraron y organizaron los virreyes a partir del último tercio del siglo XVI (Jakob Schlupmann 1993 y César Espinoza 2005: 235-268).

Sobre el asunto de la posesión y la propiedad de la tierra en Tangarará o el territorio del piedemonte andino en la que se instaló finalmente Diego de
Almagro con sus tropas y vecinos colonizadores a partir de 1534 tampoco existe mucha información. Lo que sí se puede verificar es que pocos varones que participaron de esta empresa de conquista y colonización hispana van a enlazarse con nuevas familias procedentes de España para reasentarse vía las uniones matrimoniales en las tierras organizadas bajo la modalidad de haciendas y estancias ganaderas alrededor de la ciudad de San Miguel de Piura (1588), vecinos y fronterizos a los Ejidos municipales, afirmándose en adelante el giro de la agricultura a una economía de la crianza de ganado y a la imposición del negocio de los jabones y cordobanes cuyas ganancias monetarias finalmente no se reinvierten en el corregimiento de Piura sino que se trasladan hacia otras ciudades como Sańa, Trujillo y Lima.

Durante el primer siglo de la presencia de los españoles en Piura se constata que la sede urbana y capital del corregimiento de Piura quedará subordinado a la dinámica que le impondrá la economía campesina indígena de los caciques y pueblos yungas costeros que se han levantado gracias a la dinámica mercantil que goza el pueblo y puerto de San Francisco de la Buena Esperanza de Paita (Eduardo Franco Temple 1981 y Alejandro Diez Hurtado 1989).

Invertimos entonces la historia tradicional que se ha escrito sobre Piura planteando la hipótesis de que los pueblos tallanes como Catacaos, Colán, Amotape, Pariñas, Sechura y Olmos, luego de sufrir un primer impacto que destruyó su aparato productivo, lograron a comienzos del siglo XVII, liderados por los caciques gobernadores y los cabildos de indios impulsar un programa de recuperación de su base material y poblacional reacomodándose alrededor de la bahía y puerto de Paita. En esta empresa singular que la visión tradicional ha ocultado será importante, la formación de sus pueblos y el manejo de sus tierras y parcelas comunales para articularse progresivamente a la economía mercantil y a la reproducción y a la continuidad de sus economías campesinas dispersas y al manejo ordenado y cíclico de la movilización poblacional siguiendo los ciclos climáticos anuales y distribuyendo la fuerza de trabajo familiar indígenas bajo el sistema del colonato campesino en la nueva estructura agraria y pecuaria que construyó una pequeña elite de familias de encomenderos y propietarios de tierras desde el último tercio del siglo XVI. 
Jacobo Cruz Villegas publica los documentos sobre el acceso y manejo de las tierras y parcelas de comunidad que le otorga el virrey Francisco de Toledo y otras autoridades virreinales que buscan que la sociedad indígena se adapte al modelo de colonización Habsburgo de la república de Indios. Solo el sistema de corregidores podrá controlar el funcionamiento de las encomiendas y la cobranza del tributo. Por otro lado, la pequeña urbe de Piura se mantendrá estancada por la agresión permanente del Estado virreinal al succionarle los capitales acumulados a los vecinos asentados en sus calles, solares y haciendas circunvecinas. Nada se dice en la poca documentación existente sobre el crecimiento y la habilitación urbana de este pueblo que

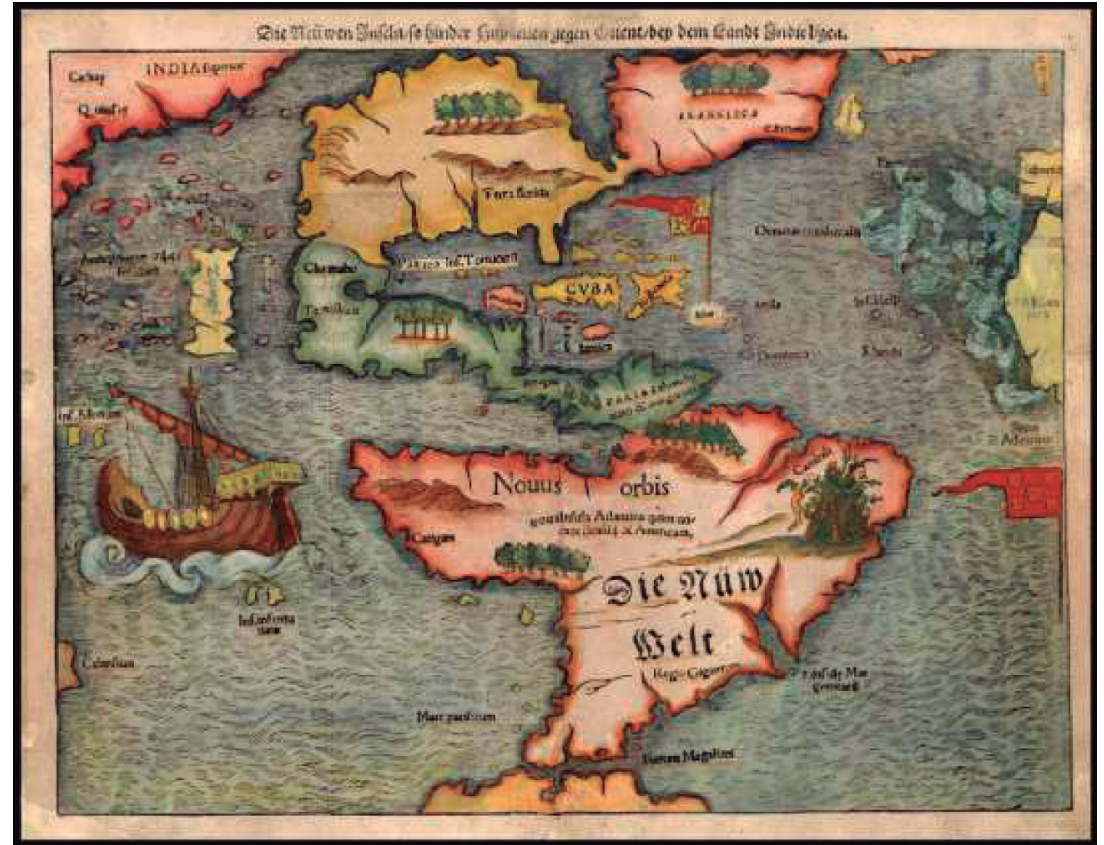

Imagen 1. Primer mapa de América, impreso en Basilea por Sebastián Muller como parte de su Cosmografía en 1540.

Fuente: Benedicto Cuervo Alvarez. 2016. La conquista y colonización española de América. En: HISTORIA DIGITAL, Vol. 16, Número 28; p. 104 https://dialnet.unirioja.es/ revista/22030/A/2016. Consultado en 15.12.2020. va a ser atacado por las fuerzas

de la naturaleza, los ciclos prologados de sequias y las intempestivas llegadas de las aguas del rio Piura y hasta las cenizas de los volcanes circunvecinos que erupcionan y la caída de las tormentas eléctricas que provocan prolongados incendios de los campos de pastizales de Sol Sol, Malingas, Tambogrande, Pabur y las tierras de Bigote (Jacobo Cruz Villegas 1982 y César Espinoza 1999).

La documentación generada después de 1588 y los primeros registros notariales sobre los contratos de compra-venta, de arrendamiento y de las compañías ganaderas muestran la asociación de los encomenderos con mujeres dueñas de tierras y un capital ganadero. ${ }^{8}$ La rearticulación de SM de Piura y el puerto de Payta a la economía ganadera y comercial de Saña y Trujillo permitirá el fortalecimiento de un pequeño grupo de vecinos en la ciudad de SM de Piura que empieza a recolonizar las tierras circunvecinas a Tambogrande, Malingas, Chapallira, Terela y Pabur. La actividad mercantil de las ciudades vecinas permitirá organizar una pequeña colonización

8 Véase anexo documental 1 y el libro de Isabel Ramos Seminario y Guillermo Garrido-Lecca Frías. 1996. San Miguel de Piura: vínculos de sangre, 1650 a 1940. Ultrapage, Piura, Perú. agraria campesina en las tierras de comunidad y el inicio del arrendamiento de espacios con bosques de algarrobas y pastizales para la crianza y el engorde de ganado de carne, cueros y la preparación de los jabones y cordobanes.

El antecedente histórico de este proceso empieza cuando en 1534 un grupo de milicianos y vecinos españoles se trasladó de San Miguel de Tangarará al piedemonte andino para construir los solares y la iglesia de lo que después va a ser conocido como San Miguel de Piura, al pie de las tierras de Moscalá, Morropón, cerca al cerro Pilan y que los vecinos en las escrituras notariales la denominaran "Piura La Vieja". En este nuevo espacio serrano se asienta Diego de Almagro con más de 100 varones para construir un pueblo con sus casas-solares, una plaza, un local para el funcionamiento del Cabildo de españoles y los depósitos en las que acumularan los tributos y las mercancías que transportan los indígenas tallanes desde el puerto de Paita y Tumbes. Este es un sitio clave para organizar una nueva economía para disponer del oro y las barras de plata que se transportan desde otras ciudades (Juan Paz Velázquez 1986 y Antonio Jaramillo Arango 2019: 39-55). 
Esta pequeña base urbana militar será también una pequeña villa que utilizará Gonzalo Pizarro, don Pedro de la Gasca y el virrey Francisco de Toledo para reorganizar un territorio que dispone de muchas ventajas como la de convivir con agrupaciones humanas nativas y mitimaes dedicadas al trabajo de la tierra, el transporte usando el ganado camélido y las mulas pardas, la fabricación de utensilios domésticos, el funcionamiento del sistema de los chasquis y la movilización de tropas y viajeros en varios espacios territoriales que abarcaban Tumbes y Guayaquil por la costa norte y Loja y Cuenca por la sierra en dirección a Quito.

Es probable que en este pequeńo pueblo de San Miguel de Piura haya residido un tiempo el clérigo secular Bartolomé de Segovia quien escribió sus vivencias y experiencias de la actuación de la tropa de Francisco Pizarro en 1551 aproximadamente. Los historiadores discuten todavía si Bartolomé de las Casas y Antonio de Herrera copiaron la información contenida en su "Relación de conquista y población del Pirú, fundación de algunos pueblos". Segovia es un personaje singular para la historia de lo que en esos tiempos se llaman "Llanos" a la geografía costeña y "naturales" a los yungas y tallanes que ocupaban estos valles. Los datos señalan que llegó a la bahía de Caraquez en 10.02.1534 acompańando a la tropa de Pedro de Alvarado para luego trasladarse a Puerto Viejo. Desde este punto Segovia se trasladó primero a Sant Miguel de Nueva Castilla (Tangarará) y también posteriormente con la tropa de Almagro a San Miguel de Piura luego de resolver los asuntos de guerra y política en Quito en octubre de 1534 y luego reunirse con Pizarro en el Cuzco en junio de 1535. Segovia no estaba solo en esta aventura sino acompańado por otros religiosos franciscanos y mercedarios que formaban parte de la tropa de guerra de Pizarro y sus hermanos hasta $1553 .{ }^{9}$

En su escrito Segovia menciona la formación singular de la geografía de la costa del Mar del Sur marcada por los manglares y una variedad de pueblos con mucha gente rica en bienes materiales y bien vestida. Señala que en el recorrido marítimo de Puerto Viejo esta articulada la Punta de Santa Elena y el puerto de Tumbez. En esta última observa una fortaleza que la han levantado los Yngas y concentra en su territorio

9 Bartolomé de Segovia 2019: 20-113. una densa población de camélidos a quienes llama ovejas. Encuentra aquí que las gentes que la ocupan son "pueblos ricos y muy domésticas".

Anota que Hernando de Soto y Belalcazar desembarcaron en La Puná para enseguida juntarse con la expedición de Francisco Pizarro; asegura que este ingresó a la costa acompańado de 200 hombres y que "llegó a Maracabilica donde pobló el pueblo de San Miguel" (118) y que explorado el valle "y vista la grandeza de la tierra y los caminos del Ynga tan anchos y tan ynsignes" decidieron ocuparla temporalmente. Aquí la tropa de Pizarro vivirá de los tributos que le entregan los naturales compuesto de patos, perdices, pescado y frutas". A este punto llegará luego la tropa de Belalcazar quien ha sido nombrado teniente de esta villa y a la cual acogerá a otra gente que llegó por mar desde Panamá y Nicaragua (Reynaldo Moya Espinoza 1994:147-171).

La información que brinda Segovia es muy importante porque permite precisar como los espańoles en una extensión de más de 800 leguas y en un tiempo muy corto van a organizar y a asentar tres pueblos poblados de cristianos e indígenas mitimaes para asegurar la guerra: San Miguel, Xauja y el Cuzco. En la costa y el piedemonte cordillerano que viene desde Guayaquil registra la existencia de montańas y manglares que tienen que dominar, cruzar la tierra de los esteros y evitar toda clase de ciénagas y montes de arboledas para asegurar la continuidad y la comunicación por lo que luego se llamará el camino real de los Yngas cruzando Tumbez, Poechos, Tangarará, Pabur, Sechura, Olmos y arribar a la villa de españoles de Saña. Para administrar estas bases poblacionales y organizar posteriormente el corregimiento de Piura como parte del virreinato del Perú los españoles insistieron en levantar y hacer funcionar una pequeña base urbana que ocupa varios lugares y que asume varios nombres que le imponen sus continuadores: San Miguel de Nueva Castilla (Tangarará, 1532), San Miguel de Piura (Morropón, 1534) y San Miguel del Villar (luego categorizado como Piura en tierras de los Catacaos, 1588).

Refundada la ciudad de SM de Piura al interior de las tierras de Catacaos (1588) se producirá entonces la formación de las primeras explotaciones para practicar la agricultura de granos como el maíz y los cereales, pero también para reproducir y engordar toda clase de ganado mayor y menor que se introduce 


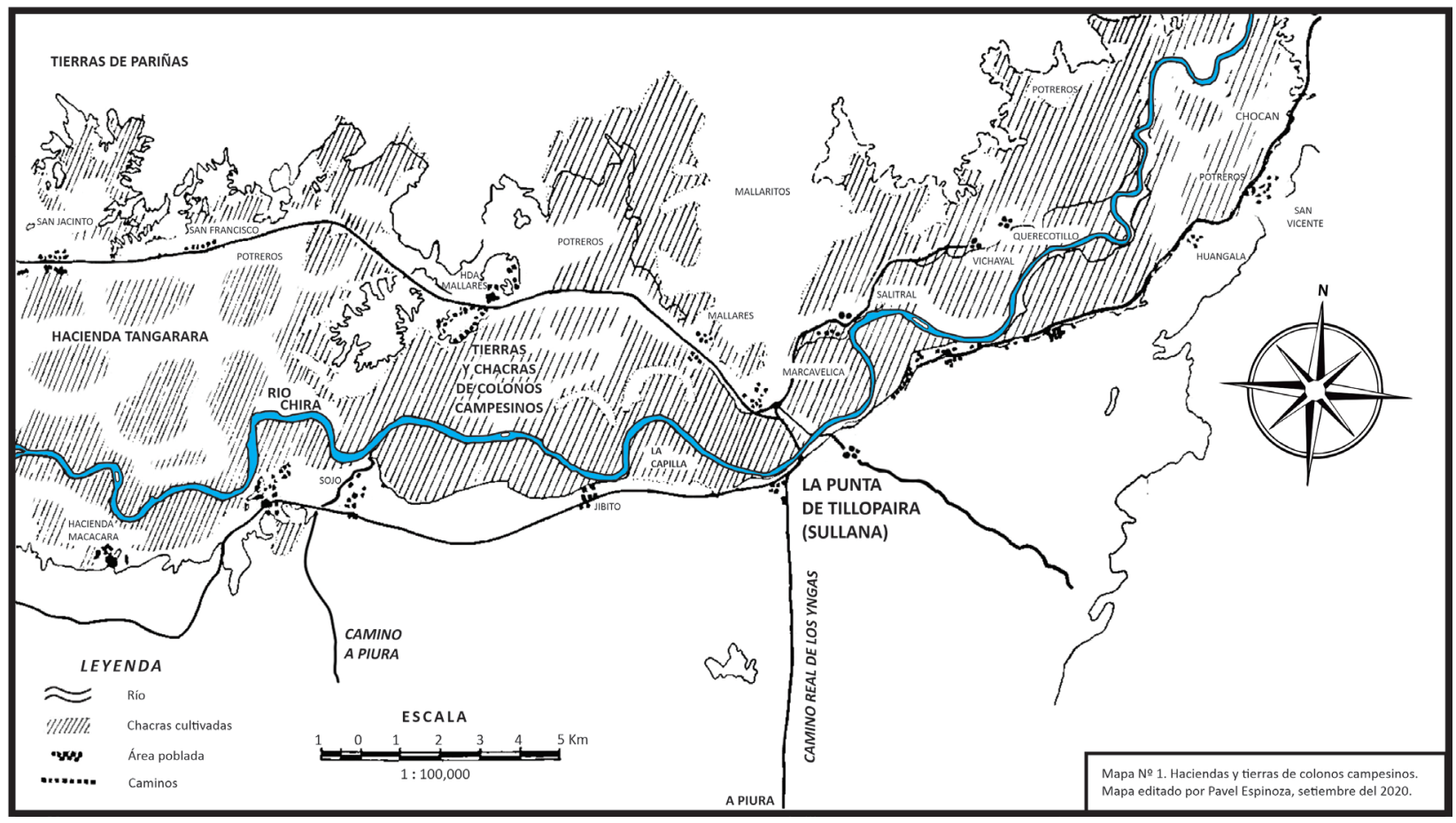

Imagen 2. El valle de La Chira y la hacienda de Tangarará, siglos XVI-XVIII.

por el puerto de Payta. Este es el espacio que primero empieza a ocuparse para luego afirmarse en las tierras del valle de La Chira, formar las haciendas y estancias de Tangarará, Huangalá y Somate, y recién iniciar la colonización de las tierras ubicadas en el piedemonte andino y con sus afluentes de agua como son las de Yapatera, Santa Ana y Chapica, casi todas compartiendo pequeños lotes y cuarteles de caña de azúcar y el levantamiento de pequeños ingenios y molinos para procesar los granos y la producción del aguardiente (Juan Montoya Guzmán 2005: 133-162),

El problema que azota la vida económica del corregimiento de Piura, las reducciones y las encomiendas fue la disponibilidad de la mano de obra indígena. El impacto de la guerra y de las epidemias fue muy alto y la población tallan y los indígenas forasteros van a ser reconcentradas alrededor de Payta y de la ciudad de SM de Piura. Los pueblos y las comunidades indígenas estaban articulados a la lógica mercantil que impone Payta, un pequeño reducto marítimo que demanda alimentos, granos, carnes, agua y leńa para mantener a los viajeros y a las autoridades que llegaban desde Panamá, pero también para sostener a un sector de la población que descasaba temporalmente en el pueblo de San Miguel de Piura para luego de cruzar el desierto de Olmos y Motupe y llegar a Saña, una villa de españoles dedicada al negocio mercantil con la sierra norte.

Es sobre este tipo de economía campesina que la economía de las haciendas va a subordinarse en un primer momento para asegurarse la mano de obra indígena y luego en un segundo momento ligado a las composiciones de tierras de 1595 , fortalecer sus economías y mercados para comprar mano de obra negra esclava y empezar a practicar el peonaje asalariado e imponer el colonato campesino que le permitirá obtener altas rentas y ganancias mercantiles que van a ser reinvertidas en la compra de tierras, herramientas de cobre y fierro, el levantamiento de pequeños trapiches y molinos, pero también de las casas-tinas para el procesamiento de los jabones y los cueros asociados a familias migrantes españolas que llegan a comienzos del siglo XVII (César Espinoza Claudio 1999).

La guerra que viven los encomenderos hasta después de 1550 provoca que las encomiendas no puedan cobrar las rentas asignadas y la población indígena tributaria se disperse y muchos mueran por el impacto cultural de la nueva forma de vida que imponen los españoles. Los conquistadores desde 1532 ingresan a la población negra esclava y se dedican algunos también al tráfico de esta mano de obra 
para ser usada en el servicio doméstico, el alquiler y el trabajo como peón de labranza de la tierra, en calidad de colono campesino y en el trabajo manual al interior de las casas-tinas y curtiembres locales.

En las tierras de hacienda empiezan a criarse y a engordar el ganado de carne caprina y vacuna, las mulas y los burro hechores alcanzan altos precios porque tienen una alta demanda para el transporte de toda clase de mercaderías; en el valle de Piura empiezan a organizarse los cercados y potreros para disponer de un capital ganadero de carnes y cueros; la posesión de la tierra agrícola todavía es precaria y la gente se alimenta de los granos y tubérculos tropicales.

En el valle de La Chira empieza a ampliarse la frontera de los potreros con sus cercos y parcelas productoras de maíz y algodón, pero también con el manejo de otros granos y frutales que atraen a la mano de obra tributaria de los pueblos comunidades indígenas circunvecinas. Los pastizales de Pariñas y Tumbes también van a ser privatizados para dedicarlos a la crianza de caprinos y ovejas. La producción de carnes, sebos y grasas y de cueros y textiles van a desembocar a Payta procedentes de los valles y pueblos de Catacaos y de La Chira. La cría de las mulas se expande en los campos de Olmos y hacia este valle y Saña se dirigen y orientan los Sechuras transportando la sal y los cargamentos de tollo y sardinas por tierra y las balsas marinas (Lorenzo Huertas 1997: 471-486).

Los vecinos de la ciudad de San Miguel del Villar dispondrán de las tierras de Ejidos, espacios municipales que alquilan las autoridades a cambio de la entrega de una renta en moneda plata o en lotes de ganado caprino. Sitios y pastos en Terela y Chapallirá, pero también al otro lado del río, en Miraflores y El Tacalá, servirán para dar empleo y provisiones alimentarias a los vecinos que residen en tres calles paralelas que se han formado junto al rio Piura y que por temporadas largas se ha convertido en una zanja agrícola y de engorde de ganado porcino debido a la existencia de ojos de agua y pastizales en sus orillas. En los alrededores de estas tierras municipales circulan los negros libertos y las familias de mestizos dedicados a la cría de pequeñas manadas de ganado caprino u ovejuno. El ganado camélido que conducían las familias tallanes todavía subsiste en grandes lotes hasta mediados del siglo XVII; se trata de llamas y guanacos que producen carnes, lanas, cueros y que sirven de medio de transporte para cruzar el tablazo de Sechura y llegar a Saña o de lo contrario subir por Tambogrande rumbo a las minas de oro de Loja y Cuenca y también para trasladar los textiles que producen los obrajes y chorrillos en esta parte de la Real Audiencia de Quito. ${ }^{10}$

\section{Los Tallanes y el motor de continuidad socio- cultural durante la dominación colonial hispana.}

Un cura jesuita, el padre Gerónimo Pallas viajó de Sevilla a Panamá y luego desembarca en la bahía de Paita a comienzos del ańo de 1618; su pluma describe las emociones que vive su mente y su cuerpo al recorrer en vivo los "Llanos" del Nuevo Mundo para describir con detalle la continuidad del mundo tallán que la lengua castellana la categoriza como sujetos indios y que antes el cronista Cieza de León en su intento de universalizar a las gentes de la costa utiliza el concepto de "yungas". En efecto, Pallas utiliza su memoria y experiencia de vida para describir el presente y anota las noticias que apuntaron otros cronistas más antiguos que le ofrecieron los datos de una sociedad que vivía sujeto a una cultura milenaria que manejaba las corrientes marinas y un territorio unido a los Chimus; así una de las sorpresas que encuentra en su recorrido del tablazo y los médanos son los grupos de camélidos andinos adaptados a un territorio caliente y húmedo como Sechura y Olmos sin olvidar apuntar que estos animales domésticos viven acompañados de sus gentes recorriendo el camino real de los Yngas unido a los puentes y tambos del Qapaq Nam paralelo a los campos de maíz y trigo:

«De la Punta de Santa Elena pasamos a vista del rio de Tumbes, y de aquí nos enmaramos para huir la corriente de Cabo Blanco, que se sigue luego y hace el paso dificultoso, viramos a la tierra y de aquella vuelta nos hallamos cerca del puerto de Paita, donde desembarcamos el día de año nuevo de 1618, dos meses enteros después que nos hici-

10 Véase: Caillavet, Chantal.2000. II.4. Los mecanismos económicos de una sociedad minera: intercambios y crédito. Loja: 1550-1630; pp. 273-308. En: Etnias del Norte. Etnohistoria e historia del Ecuador. Institut français d'études andines, Abya Yala, Casa de Velázquez. Colección Travaux de l'IFEA No 106, Lima, Perú. https://books. openedition.org/ifea/2870. Consultado en 07.10.2020. 
mos a la vela en Panamá (171). En cinco grados y un cuarto de la banda del sur tiene su asiento la ciudad de Paita, población de Españoles y de Yndios Barbados, que es singularidad entre los indios del Occidente porque todos naturalmente son lampiños y sin pelo en el rostro y cuando les nace alguno lo arrancan luego cuidadosamente, porque afectan sobremanera el no tener barbas ni mostachos. El puerto es grande y bueno, y principal escala de todo el Mar del Sur, ahora se vaya del Perú a Nueva Espańa o ahora se navegue desde Tierra Firme hasta Chile. Y a esta causa, aunque el pueblo es pequeño, esta de ordinario abastecido de mantenimientos para dar refresco y mata olaje a las Armadas, y a los navíos del trato que a el aportan. También suele ser término de la navegación de Panamá para arriba, porque desembarcando los mercaderes y pasajeros en Payta se van desde aquí por tierra a la Ciudad de los Reyes, que abra doscientas leguas y después de avellas andado, en veinte y cinco o treinta días, suelen aguardar muy de espacio que suban las naves con la ropa, y casi sin más gente que la de mar y de guerra si los navíos son de Armada.

El corregidor de Payta tiene su asiento en la ciudad de Piura, que está de allí doce leguas, y es tradición de los vecinos encomenderos desta ciudad, conforme ellos cuentan, que de Piura se derivó el nombre de Pirú, porque los primeros espańoles, dice, que descubrieron y navegaron el Mar del Sur, luego como saltaron en la costa procuraron saber cuál fuese la población y ciudad mayor y más principal de estas partes, y que los yndios con quien hablaban les respondían Piura, Piura, y ellos alterando el vocablo nombraron Pirú a todo el continente de tierras que después conquistaron. Y, si esto pasó así, causame admiración que los historiadores antiguos de las Indias como son Pedro de Cieza de León, Francisco López de Gómara y el contador Agustín de Zárate, ni el P. Joseph de Acosta no lo supiesen, si bien parece que esto puede pasar con lo que ellos dijeron, y después recopilaron otros, acerca de que Pirú viene de Perú nombre de un Yndio, o de Pelú nombre apelativo que significa río o del nombre propio de un río llamado Pirú o de Piura que significa granero y silo, remitiendo la averiguación de lo que razón de esto se haya de estimar por más acertado a lo que el doctor Juan de Solorzano Pereyra, antiguo Catedrático de Prima de Leyes en Salamanca y meritísimo oidor de la ciudad de los Reyes, en los libros que está acabando de Indiarum Iure Lib. 1.c.3 (172).
«Luego como la fragata salió del puerto de Payta tratamos los demás de nuestra partida, y hubo suficiente número de mulas aunque mal aprestadas, porque en el Pirú los que caminan por tierra llevan propia silla y freno, como y también su almofrex (?) con cama y pabellón, y a veces toldos para armar en la pampa y guarecerse de las inclemencias del tiempo, y partes ay donde se carga no solamente la comida de un día para otro sino el agua y todo que han de beber las personas, y la leña con que se ha de guisar la comida, y dije el agua de las personas porque las cabalgaduras suelen pasar tres días caminando sin beberla; nosotros hubimos de caminas sobre enjalmas con una frazada cada religioso, que le sirviese de toldo, de pabellón y de cama, y con este avió partimos de Payta el día de los Reyes del año de 1618. Llegamos el siguiente a la ciudad de San Miguel de Piura, doce leguas del puerto que se andan en dos jornadas, durmiendo la noche en el campo, porque no ay pueblo, ni más que una ramada desierta en mitad del camino. Vimos aquí la primera vez el ganado de los Yndios, que son ciertos animales mansos y espaciosos del tamańo de un ternero con el pescuezo largo y levantado en alto derecho, porque no es todo parecido al del camello, casi sin cola, patihendido y guedesudo, con unas lanas ásperas de diferentes colores como suelen ser los caballos. Llaman los españoles a estos "carneros», sin tener cuernos ni parecérseles en otra cosa alguna. Los (181) yndios no tuvieron nombre especial para ellos sino con el general de ganado, que en su lengua dice Llama. Júntanse pues estas Llamas o carneros de la tierra, manadas, que sirven para los trajines de mercaderías en recuas de 500 y de 600 , y a veces de mil cabezas, llevan de tres a cuatro arrobas de carga, y caminan poco más de tres leguas por jornada. La carne es de buen sabor para los yndios, y la de los corderos aventajada. De Piura adelante se encuentra un despoblado de arenales sin agua ni yerba para las cabalgaduras en tres jornadas, ni aun camino abierto que pudiésemos ver, porque el viento mueve y levanta arenas de unas partes a otras borrando las pisadas y desfigurándolo, de suerte que a no ser diestrísimos los yndios Olmos, que sirven de guía, se hubiera de caminar como en la mar con aguja para salir a poblado dentre aquellas suertes. Acabase el despoblado en Olmos, pueblo de yndios, y que su principal ocupación es tener mulas para alquilar a la gente que va de Payta a Lima, y con esto son ladinos todos, y ninguno ay pobre. En un lugar que se nombra Tucumi, nos dijo el Padre Doctrinero que la mayor parte de sus feligre- 
ses, acabando de predicarles en la iglesia y de hacerles decir las oraciones, se iban a idolatrar en partes escondidas, cosa que causó gran lastima y sentimiento el oirla. De aquí pasamos a Lambayeque, pueblo grande y de buen temple, en tierra abundante de trigo y de frutas de Castilla y de las Yndias, riégala un rio deleitoso y lleno de pescado, sus moradores muestran ser buenos cristianos y no son mal entendidos. Encuentranse adelante unos paredones residuos de aquel gran camino real que en tiempo del Ynga Guaynacaua, o como dice los que mejor hablan Guayna Capac, se labró para venir por los Llanos desde la ciudad del Cusco hasta Quito, distancia de 500 leguas, con gruesas tapias bien altas de una y otra parte, de suerte que los indios que caminaban no descubrían los campos de los lados, ni aun podían salir fuera del camino sino a ciertos trechos donde estaban casas a manera de ventas, y en ellas repartidos Chasquis o correos, que unos recibían los recaudos a boca de los otros, y desta manera se iban continuando corriendo el un chasqui hasta el tambo o albergue donde estaba el otro, y como los yndios no tuvieron letras las cartas que escribían y los despachos del Ynga eran estos». ${ }^{11}$

Las crónicas más tempranas que informan sobre la presencia de los conquistadores españoles en el valle de La Chira señalan que la autoridad Ynga que controlaba este microespacio estaba asentada en un sitio llamado Poechos, un lugar estratégico para el control del agua y el funcionamiento de una red hidrológica que se expandía hasta Amotape, cerca al mar, y que terminaba bañando las tierras de labranza en el extenso valle de Colán. A lo largo de este valle se encontraban en los bordes y orillas varios asentamientos humanos dispersos. Faltan mayores estudios arqueológicos que permitan establecer que los tallanes formaron parte de una red de ciudades-estado que luego fueron conquistados por los Chimus (Susana Aldana 2018: 126-174).

\section{Hacia una biografía política y cultural de la tierra y la resurrección de la sociedad tallán.}

11 P. Gerónimo Pallas. 1619 (2006: 181-182). Mission a las Indias con advertencia para los religiosos de Europa, que la hubieren de emprender, como primero se verá en la historia de un viaje, y después en discurso. CSIC. EEHA. El Colegio de México. Universitá Degli Studi di Torino. Estudio y transcripción José J. Hernández Palomo. Madrid, España.
Una sistematización de las crónicas más tempranas y los trabajos publicados hasta 1994 lo realiza la antropóloga Anne-Marie Hocquenghem (AMH) quien usando el análisis comparativo busca reconstruir la ruta de ingreso al territorio de los tallanes en 1532. Para esto utiliza los escritos publicados por los cronistas que acompañaron a Pizarro desde Tumbes a Serrán, examina, consulta y compara los datos y la lista de los tambos de 1543 de Vaca de Castro, y la Relación de Repartimientos y los caciques de 1548 que ordenó levantar don Pedro de la Gasca. AMH con esta información realizó un recorrido personal de casi todo este territorio que los tallanes habían dominado, siguiendo la ruta de dos grandes ríos y sus afluentes e identificando los tambos y caminos reales de los Yngas que vinculaban el espacio de los Llanos con la Sierra. En sus escritos busca comparar sus propuestas con las que hicieron otros narradores sobre la ubicación de las poblaciones, los centros administrativos y ceremoniales y los posibles lugares de concentración de las elites Yngas y Tallanes. Lo interesante esta investigación es que verifica de manera preliminar como la población tallan estaba concentrado en dos valles. En La Chira, entre Tangarará y Marcavelica, y en el Piura, entre Pabur y las tierras de Catacaos (Narigualá). Los Tallanes y los Yngas manejaban un complejo sistema hidráulico para manejar y distribuir el recurso hídrico en un valle que tiene agua permanente desde Poechos y otro territorio que solo dispone del recuro hídrico solo cuatro meses del año (Pabur) (Anne Marie Hocquenghem 1993).

En efecto, al interior de estos dos microespacios claves los Yngas habían asentado a los mitimaes y a los caciques gobernadores para controlar a la población tallán. Y es en estos dos lugares donde se asienta Pizarro y su tropa bajo la forma de una "ciudad" que funciona como una base político y militar para asegurar su empresa de la conquista del Tahuantinsuyo. La primera ciudad se llama "San Miguel de la Nueva Castilla" y se levanta en tierras de los indios del cacique de Tangarará y la segunda, creada a partir de 1534 por Diego de Almagro, será conocida como "San Miguel de Piura", asentada casi al pie de los Andes y vecina a las tierras del cacique de Pabur. En estos dos espacios microterritoriales funcionaba un complejo sistema agrario que permitía a los Yngas disponer de alimentos y un conjunto de materias primas que utilizaron para avanzar en su proyecto de ex- 
pansión político y militar hacia Quito. Los extensos campos y cerros de Malingas, Yapatera y Morropón también concentraban muchas cabezas de camélidos que servían para alimentar a esta población y de igual forma para el transporte del maíz y el algodón entre el piedemonte andino y las costas del Mar del Sur (Astuhuamán 1999: 38-44 y Hocquenghem 1991: 309-348).

Sobre esta base productiva los tallanes habían levantado una infraestructura de comunicación en la que destacaban los caminos reales y los tambos, pero también una diversidad de comunidades yungas especializadas, unas dedicadas a la pesca y al transporte marítimo, otros a la producción de la sal y el manejo de los bosques. No puede olvidarse que, desde estas playas de Tumbes, Sechura, Payta, Colán, Amotape y Pariñas, las flotas de las balsas acompañaron la empresa marítima de Tupac Yupanqui rumbo hacia la Polinesia y la exploración del Mar del Sur que a finales del siglo XX fue estudiado por el historiador José Antonio del Busto, reforzando y confirmando de esta forma el gran desarrollo tecnológico y social que habían alcanzado las poblaciones yungas y tallanes en el siglo XVI (del Busto 2017 y 1969). ${ }^{12}$

Ahora bien, en 1532 el territorio de los tallanes estaba bajo el control político de los Yngas, de Atahualpa, y en Poechos residía un cacique gobernador a quien Pizarro y su gente entrevistó y buscó información sobre la guerra que mantenían Huáscar y Atahualpa. Los cronistas son muy escuetos y controversiales sobre las noticias que brindan sobre este hecho porque además en el escenario están presentes los agentes informantes como Cinquinchara quien luego de observar y de recoger información oral sube a la sierra de Huamachuco para entregarle información directa a su señor Atahualpa. Pizarro sabe de este tipo de movimientos de los agentes enviados y sus cronistas lo registran; pero a este accionar se suma otra actividad que ocupa a los españoles quienes estaban recolectando piezas de oro y de plata y andaban ocupados en fundirlos y utilizarlos para la compra de armas y de traer un mayor número de gente que los acompañe a subir los Andes. A todo esto se suma que la noticia del ingreso de Pedro Alvarado a Quito, la marcha de Benalcazar para detenerlo y el reinicio de

12 Sobre las rutas marítimas entre Tierra Firme y Tumbes, y los balseros en el Mar del Sur puede revisarse los trabajos de Esteban Mira Caballos 2018y Luis Miguel Glave 1991 y 1993. una nueva campańa de reclutamiento de un mayor contingente de indígenas de las parcialidades yungas que sirvieran en calidad de soldados para proseguir la campaña militar y movilizarse hacia Tambogrande y Pabur, otros espacios rurales en la que tenían noticias de que la gente tallán mostraba signos de resistencia para luego prepararse y ascender a la sierra de Cajamarca (Mariano Bonialian 2019; Franklin Pease 1991; y Martin Rubio 2014: 83-202 ).

Es muy poco lo que todavía se puede conocer acerca de los momentos de prosperidad de la economía y la sociedad de los tallanes, y las crónicas solo se limitan a presentarlos gozando de cierta autonomía y de ser gentes que vivían dispersos entre los médanos y montes de arena y algarrobos. Tampoco nada se sabe sobre el impacto de la sequía y la guerra de los Chimus para controlar este valle e imponer su tejido social y político y menos los cambios que introdujeron en su paisaje social (Diez Hurtado 1987 y Luis Guzmán et al. 1996).

Los datos más interesantes que ofrecen los cronistas se refieren a los caminos y tambos que permitían una fluida comunicación de la población tallan entre el piedemonte andino de Poechos y Pabur con las bahías y puertos de Tumbes y Payta. Se trata de un Qapaq Nam o "camino real de los Yngas" que funciona hasta finales del siglo XX y que sale de Tumbes para abrirse varias rutas hacia el sur; el primero cruza Pariñas-Máncora y se enlaza con La Huaca y Sojo para dirigirse hacia el tambo de Catacaos-Guamará para de allí, luego de llegar a Congorá, terminar en las playas de Payta. La otra ruta esta casi pegada al piedemonte andino pues de Tumbes llega a Poechos y desde este lugar cruza Tambogrande para articularse a otros caminos y a una densa red de acequias y canales de riego entre Yapatera y Morropón. ${ }^{13}$

Entre 1532 y 1548 los conquistadores españoles se apropiaron de las mejores tierras de los tallanes para crear sus estancias ganaderas y pequeñas haciendas subyugando a los nativos para que trabajaran en ellas, reconcentrando a otras poblaciones como los cañaris que fueron trasladadas para la guerra desde lo que después se llamó la Audiencia de Quito. En este proceso histórico se ensayó la fundación de una primera base militar en Tangarará a la que se le im-

13 Un bloque bibliográfico sobre esta región de tránsito se puede encontrar en Anne Marie Hocquenghem; Zaida Lanning y Pierre Gondard, 1999 y Víctor Velezmoro 2004: 35-63. 
puso el nombre de "San Miguel de Nueva Castilla", pero pronto la resistencia de los tallanes se expresó en la fuga y dispersión hacia los montes y dunas desérticas quedando despoblado este valle, y en 1534 Hernando Pizarro tuvo que migrar con sus acompañantes al pie de la sierra de Morropón y usando los recursos humanos que pudo encontrar logró levantar una pequeña ciudad con piedra y cal que empezó a llamarse San Miguel de Piura, el mismo que empezó a funcionar como una nueva base político y militar ya dirigida por Diego de Almagro para facilitar el ingreso de nuevas tropas y armas que necesitaban los gobernantes españoles y proseguir la guerra contra los Yngas del Cuzco (Nadia Correa 2004: 96-153 y Hocquenghem 1989:17-41).

Entre 1548 y 1578 permaneció aquí un grupo de familias españolas residiendo en este sitio que empezaron a llamar los viajeros y visitantes como "San Miguel" de Piura, ubicado al pie de un cerro desde el cual se expandía un espacio agrícola y pecuario con sus montes y canales de riego, ${ }^{14} \mathrm{y}$ en la que nuevamente y por segunda vez fracasan en su intento de consolidarlo como una empresa de colonización agro-ganadera y mercantil. César Astuhuaman y un equipo de arqueólogos ha estudiado en detalle la arquitectura de esta pequeña ciudad en la que los espańoles levantaron con apoyo de los religiosos mercedarios una primera iglesia que fue destruida por la guerra de los encomenderos, la agresión de la naturaleza y la resistencia de los indígenas que la abandonaron huyendo a vivir al campo en busca de una vida mejor. Es posible que con las acciones del virrey Francisco de Toledo empezaran a recuperar el antiguo sistema hidráulico tallán, pero es muy escasa la información existente que pudo lograr la investigadora Anne-Marie Hocquenghem y los miembros de la comisión franco-alemana para tener una idea total de su importancia para la región. ${ }^{15}$

El desencadenamiento del FEN de 1578 terminó por obligar a las familias y encomenderos espańoles residentes entre San Miguel de Piura, Pabur y

14 Esta pequeña urbe será abandonada desde 1578 para ser conocida como "Piura La Vieja" y después formar parte de una hacienda bajo el nombre de "Monte de los Padres". Puede consultarse César Astuhuaman y Fernando Vela Cossio 2010: 113-116 y Hocquenghem 1994:1-67).

15 Una actualización de la documentación y reflexiones sobre este asunto se puede encontrar en Hocquenghem 1998 y Aurelio Rodríguez y Carlos Campos 2010: 84-96).
Morropón a trasladarse hacia la bahía de Payta acompañados de negros esclavos y libertos, de familias indígenas cañaris y de un pequeño capital ganadero y monetario. El golpe económico que sufrieron este grupo de gentes con el traslado desde un lugar rodeado por bosques de algarrobo a otro en la que escaseaba el agua pudo solucionarse con una temporal subordinación a los caciques y autoridades indígenas que rodeaban al pueblo indígena de Payta y también a las relaciones que establecieron con los caciques de SL de Colán y Catacaos.

Para este tiempo muchas de las familias españolas habían establecido relaciones con estas autoridades indígenas que controlaban prácticamente los valles de Tumbes, La Chira, Piura-Catacaos, Olmos-Motupe. Los caciques y las tierras se habían legitimado por el virrey Toledo quien luego de asignar las encomiendas y las tasas tributarias estableció la legitimidad de los Cabildos de Indios y el vasallaje de estas poblaciones al rey Felipe II.

Las familias españolas residentes en Payta van a articular sus vínculos comerciales y patrimoniales con el virrey que gobierna en Lima pues se requería con urgencia asegurar la vigilancia y la seguridad del movimiento marítimo de las flotas de galeones y de la Armada del Sur que trasportaba el oro y la plata extraída desde las minas de Potosí y el ingreso por mar y tierra de los funcionarios políticos, las tropas del rey y de toda clase de viajeros que empezaron a introducirse y a asentarse en las ciudades que habían levantado en la costa norte del Perú.

En buena cuenta, hasta 1587 al interior de esta pequeña bahía convivían los indígenas del pueblo y la comunidad de San Francisco de Payta y las familias de españoles y criollos dedicados al comercio y a la vigilancia de la cobranza de los tributos y alcabalas y almojarifazgos del rey en una base urbana bajo el nombre de San Francisco de la Buena Esperanza de Payta, un microespacio marítimo que cumplía la función temporal de capital del corregimiento de la provincia de Piura y en la que se habían reasentado los religiosos mercedarios, algunos encomenderos y el corregidor don Alonso Forero de Ureña.

En esta pequeña población de Payta entonces vivían los descendientes de los tallanes, nativos y forasteros, indios tributarios que compartían su vida cotidiana con otras poblaciones indígenas como los sechuras, amotapes, parińas, colanes y Catacaos. Esta 
población tallán entrega su trabajo productivo y de servicios a los comerciantes que han decidido con el apoyo del virrey asentarse en este lugar estratégico de llegada y salida de toda clase de embarcaciones desde Panamá y Sevilla.

Lo interesante de esta historia social es que en Payta se encuentran concentrados varias poblaciones indígenas de diferente origen étnico; en el tablazo y en sus playan residía una pequeña urbe multiétnica en la que todavía se habla el tallán y posiblemente el quechua y el castellano. Hacia este lugar llegan casi a diario los colanes en sus balsas trasladando la leña, el agua y la sal. Pero también los sechuras con sus flotas de balseros llevando el pescado y los mariscos. Finalmente, confluyen los Catacaos con sus camélidos que llevan el maíz y el trigo o las recuas de mulas y burros que se encargan de trasladar la manufactura textil, los biscochos y las carnes para el consumo local. En este pequeño puerto se reproducen los elementos de la cultura tallán y sus formas de vida comunitaria (Fernando Vela 2010 y Luis de Villanueva et al 2004: 267-294).

Los escritores locales han minimizado esta experiencia histórica de vida presentándolos como gente bárbara e incivilizada, aislados y dispersos en el tiempo y viviendo en permanente explotación y miseria. Todo lo contrario, una nueva lectura de la documentación ubicada nos permite plantear que los diferentes agrupamientos humanos que formaron la etnia tallan sobrevivieron al colapso y a la sangrienta conquista española, labrando la tierra, manejando el agua para enfrentar los prolongados ańos secos, construyendo sus tecnologías para abastecerse de los utensilios para la vida cotidiana, en suma, reprodujeron su antigua herencia nativa de manejar la naturaleza sin destruirla. Los tallanes destacaban por una distintiva forma de vida que en el siglo XVIII un vasco mercader como don Joaquín de Helguero solo buscaba ocultarlo con su lenguaje de desprecio y racismo usando el discurso y el lenguaje liberal euroccidental que incluso pervive en la actualidad. ${ }^{16}$

En el siglo XVII la cultura tallán estaba viva al interior de lo que los españoles llamaban el corregimiento de Piura. Desde España se impondrá un sistema llamado la "República" que buscará conservar al interior de este microespacio a los tallanes y a sus des-

16 Bruno Revesz et al 1997 y César Espinoza 2018: 107-126. cendientes, también incluir en sus parcialidades a los mestizos, y todos sometidos a las nuevas autoridades que empiezan a funcionar bajo el modelo del cacicazgo y el Cabildo de Indios con sus alcaldes y regidores.

La reproducción de la sociedad y la cultura tallan avanzó lentamente, pero con grandes dificultades porque ahora la población tributaria debería entregar sus excedentes materiales y una cantidad de fuerza de trabajo al corregidor, una renta al cura, cuotas de trabajo como mitayos a los encomenderos y tiempo de trabajo como colonos y yanaconas campesinos a los dueños de la tierra y estancias ganaderas. Este proceso de funcionamiento del corregimiento no ha sido estudiado, solo se ha empezado a examinar a los agentes que succionaban el trabajo excedente de los indígenas, a los encomenderos. Lo que falta ahora es comprender cómo es que se adaptaron los indios tributarios y no tributarios a un mundo que empieza a ser remodelado drásticamente por fuerzas que impone la cultura hispánica representada por los corregidores, los curas y los alcaldes de indios. Frente a las dificultades que se presentan, los curas deberán aprender a manejar varias leguas que practican los diversos grupos que conforman la etnia tallán y de esta forma sujetar el alma y las emociones de la gente dedicada a la labranza de la tierra que encontraba en el agua no solo proveniente del cielo o del río sino también de las lagunas y los puquiales (jagueyes) a sus protectores y reproductores de su tiempo y vida colectiva (Fernando Vela 2014: 25-58; Pavel Elías 2004: 211-269).

El examen de los padrones poblacionales que han realizado los historiadores y antropólogos Lorenzo Huertas, Alejandro Diez Hurtado y Pavel Elias Lequernaque muestran las dificultades para conocer sus movimientos y lo que hasta ahora presentan son proyecciones pues la gran mayoría practicaba todavía el principio de organización social de la dispersión en múltiples territorios para complementar sus economías familiares. ${ }^{17}$ De tal forma que los tallanes sobrevivieron a la fuerza del colonialismo reconstruyendo una parte de su sistema económico y laboral, de complementar sus economías agroganaderas con la economía de intercambio que se practicaba en una bahía y puerto clave como fue Payta recuperando de

17 Lorenzo Huertas 1991: 489-500; Alejandro Diez Hurtado 2006: 107-127 y Pavel Elias Lequernaque 2004. 
esta forma y dándole continuidad a las tradiciones de intercambio que por tierra y mar practicaron sus antepasados con los Chimus e Yngas fortaleciendo de esta forma sus costumbres, creencias y estrategias de vida conforme avanzaban nuevas formas de colonialidad del poder que imponía la monarquía hispana (María Rostworoski 1961: 25-35 y 1982: 507-543).

Fue un corto tiempo que duró esta especie de resurrección de la cultura tallán liderados por los caciques yungas de Colán y Catacaos que estaban presentes en la economía de Payta. Los pueblos indígenas recuperan su identidad construyendo una iglesia y aceptando la religión cristiana y la legislación indiana que reordena una parte de su ser social. Las familias que cultivan la tierra viven dominadas por un paisaje sagrado, pero también por una variedad de lugares espiritualmente importantes que busca liquidar un comisario de la Inquisición, el bachiller Juan de Mori. Las parcialidades como Narigualá y Cucungará viviran de la agricultura y de la lluvia adorando a los dioses y a sus muertos, pero también al dios cristiano que ha empezado a desplegarse hacia otras parcialidades (Lupe Camino 1982 y Oswaldo Fernández 1998).

Los labradores de la tierra necesitan de una variedad de utensilios de arcilla para conservar sus alimentos, pero también para transportarlas y usarlas en la vida cotidiana. Simbilá recupera la tecnología de sus gentes para proveer de este tipo de botijas y vasijas manejando la arcilla y usando la leña del algarrobo y del hualtaco; los artesanos combinan una variedad de sustancias para darle color a sus objetos que los acompañan en su vida diaria y otros que van a ser intercambiadas por las vainas de semillas de los algarrobos y toda clase de granos y tubérculos para el consumo familiar. El trabajo manual con la tierra y la manufactura textil y arcillosa son entonces ejemplos de una continuidad cultural entre los tallanes y sus descendientes que van articulándose lentamente a la lógica de la economía mercantil que introducen los comerciantes y encomenderos en lo que ahora se llama la provincia de Piura. Anne Marie Hocquenghen, Susana Monzón y Juan Echeandía han registrado la permanencia de una cerámica utilitaria paleteada en Pabur y alrededores (Anne Marie Hocquenghen 1993; Susana Monzón 1991:594-596 y Juan Echeandia y Renate Wisbar 1990: 15-29).
La población tallán no vivía entonces aislada en esta zona del norte del Perú; sus líderes buscaron desde que apareció por Tumbes Francisco Pizarro la forma de entroncarse entre sí y acoplarse a la aventura de una guerra que movilizó a los españoles hasta 1587. En la guerra contra los Yngas muchos tallanes fueron reclutados para movilizarlos en los ejércitos que recorrieron en los Andes. Liquidado un sector de los líderes y caciques, sus descendientes buscaron reafirmarse en el nuevo patrón de asentamiento humano tributario que impusieron La Gasca y el virrey Toledo. Para esta última fecha, los registros fiscales señalan ya con claridad la existencia de dos grupos sociales: los indios originarios y los indios forasteros. Cada uno recibirá del corregidor un territorio que les permitirá obtener la subsistencia y la renta tributaria. Las autoridades españolas pronto descubrirán que esta población no puede sostenerse fijo en un espacio asignado, sino que por el contrario, los caracteriza la dispersión, la migración temporal, pero también la fuga y el traslado a otra jurisdicción provincial (César Espinoza 2013:339-368).

Con el virrey don Francisco de Toledo y las reducciones se buscó censarlos y agruparlos alrededor de un centro poblado en la que se levantaría primero una capilla y luego una iglesia en medio del rugido de las aguas del rio Lengash y la fuerza de los vientos y el movimiento de los médanos desérticos que cruzaban los caminos, puentes y lagunas entre Guamará y Letirá (César Espinoza 1999).

Los que empezaron a residir en el centro poblado son las familias de los caciques y las autoridades de las parcialidades; los alcaldes y regidores, los alguaciles y escribanos, pero también los ayudantes de los curas y vicarios de los pueblos se comunican con los representantes de la otra "República" compuesto por autoridades blancas, en su mayoría españoles residentes en la capital de la provincia, San Miguel de Piura a partir de 1588. Aquí residirá el corregidor que representa al poder dominante quien junto a los alcaldes $y$ regidores administran los negocios y la justicia en toda la provincia.

La presencia del corsario Cavendish en Payta (1587) y la derrota y destrucción de la fuerza militar espańola es la tercera vergüenza que sufren los espańoles que viven en este pequeño puerto. Nuevamente, los encomenderos y comerciantes sobrevivientes al ver destruido la ciudad y sus depósitos mercantiles 
no les queda sino fugar por el tablazo y dirigirse a buscar refugio y ayuda, por el norte, a San Lucas de Colán, y por el sur, al pueblo de San Juan Bautista de Catacaos. El virrey gobernante, el Conde del Villar y el corregidor Alonso Forero de Ureña nada pudieron hacer para evitar la destrucción de la bahía y puerto de Payta pues estaban enfrentados ambos en asuntos e intereses privados antes que programar una acción conjunta contra un corsario que ya había saqueado y destruido otras poblaciones en el Mar del Sur del Perú. El impacto de la presencia de Cavendish fue tan intenso que el Conde del Villar fue presionado por las autoridades reales para que refundara la ciudad de SM de Piura al año siguiente al interior de las tierras que administraba la comunidad indígena de SJB de Catacaos y se rehabilitara la vigilancia y el funcionamiento del pueblo de SF de Payta. ${ }^{18}$

Este es el momento singular para que se asentara definitivamente el modelo y sistema de los Habsburgos, creándose una sociedad binaria de españoles e indígenas, y en la que al interior de cada una de estas se iban agregándose otras categorías sociales (caciques, mestizos, pardos, forasteros, etc.) hasta su reemplazo por el modelo de los Borbones. Los contenidos de jerarquización socio-política de las "republicas" son contundentes en su expresión territorial, arriba los blancos españoles y abajo los indios tallanes esta vez y a partir del siglo XVII organizados en pueblos y comunidades indígenas como Catacaos, Sechura, Colán, Payta, Amotape y Olmos.

18 La literatura sobre Thomas Cavendish es abundante porque recorrió el Brasil y luego invadió y asaltó casi todos los puertos del Mar del Sur hasta Tierra Firme. Sir Francis Drake, Thomas Cavendish, William Dampier. 1910. Famous english naval adventurers and circumnavigators of the Globe. Promoters of Great Britain's Supremacy on the Sea. Their Lives and Voyages. History of the Bucaniers. The Werner Company, New York and Akron, Ohio, USA. Johnstone, Christian. 1844. Lives and voyages of Drake, Cavendish, and Dampier. Including an introductory view of the earlier discoveries in the South Sea, and the history of the Bucaniers. New York, USA. Araujo, Luis Rafael. 2019. Perigo que vem do mar: o ataque de Thomas Cavendish ao Espíritu Santo Colonial. En História em Rede, 24 Augusto.

https://medium.com/@historiaemrede/perigo-que-vem-do-mar-oataque-de-thomas-cavendish-ao-esp\%C3\%ADrito-santo-colonial88e471cf8f3f. Consultado en 12.10.2020. Costa Vigo, Luis M. 2017. Por no yr tan solo. Redes clientelares y dinámicas de poder en el virreinato del Perú: el caso del gobierno del virrey conde del Villar, 1585-1590; pp. 22-39. En Parientes, criados y allegados: los vínculos personales en el mundo virreinal peruano. Instituto Riva-Agüero. Lima. Recuperado de: http://ira.pucp.edu.pe/libreria/publicaciones/ parientes-criados-y-allegados-los-vinculos-personales-en-el-mundovirreinal-peruano/
San Miguel de Piura desde 1588 es un pequeño centro poblado que se asienta a un costado del rio Lengash y que solo se expandirá entre dos extramuros ubicados entre la Iglesia del Carmen y la Iglesia de la Merced que no supera un poco más de las cinco cuadras de largo. Hasta el siglo XVIII tiene constituido paralelo al rio solo tres calles consolidadas y el resto son barrios temporales y precarios que aparece y desaparecen con las inundaciones del rio y las lluvias torrenciales cuyas aguas circulan entre los médanos que la rodean. De allí que hasta Vargas Llosa a mediados del siglo XX la conoció como la pequeña "aldea" pues su perímetro se levantó solo para acoger a la gente blanca y mestiza mas no soportaba la presencia de indígenas y los negros esclavos y libertos, los mismos que fueron entonces reubicados en los llamados "extramuros" o barrios del sur y del norte que describe con mucha libertad e ironía don Enrique López Albújar. ${ }^{19}$

Bajo el gobierno de los Habsburgos y la expansión del comercio local los residentes de la ciudad se trasladaron al campo, no solo buscando tierras de cultivo y agua para el riego, sino también de lugares en los que hubiera fuerzas espirituales como La Punta de Tillopaira (Sullana) que pensaban que los protegerían de un mundo rodeado de muchos enemigos. Producto de la guerra de los espańoles contra los tallanes y los Yngas, casi todos los valles que contienen la provincia de Piura quedaron prácticamente deshabitados y dispersos los tallanes sobrevivientes. A comienzos del siglo XVII empiezan a registrarse con mayor fuerza la formación de las primeras haciendas y estancias ganaderas. Las tierras de labranza existentes entre Poechos y Tangarará-Amotape empiezan a disputarse; hacia este espacio se trasladan los indios tributarios y mitayos de los pueblos indígenas para construir canales y acequias de drenaje para ampliar la frontera agrícola del maíz y del algodón. En los espacios de lagunas se levantan potreros para engordar el ganado y en las orillas del rio se levantan los talleres

19 Muchos piensan y escriben que la ciudad de San Miguel de Piura estuvo solo poblada por blancos/as criollos; en la refundación de 1588 se asienta a una colonia de indígenas mitimaes cañaris a la espalda de la casa del Cabildo, que después es nombrado como el barrio de San Sebastián y por los negocios y compradrazgos con Sechuras y Catacaos, este espacio "extramuro" o "barrio sur" servirá de residencia temporal también a los viajeros de otros pueblos mestizos e indígenas. Véase Enrique López Albújar, "Matalache” (1924) y "De mi Casona” (1928); y Enrique López Albújar y Carol Beane 1997: $11-15$. 
para la preparación de jabones y cueros, las tinas y curtiembres se multiplican en este valle que dispone de un rio con agua permanente.

Así conforme avanza el siglo XVIII llegan a Piura nuevos contingentes de la sierra de España, familias vascas, sevillanas y catalanas que no encuentran lugar ni status en Lima y que migran hacia el norte y se estacionan en Piura, así ocurrió con los Seminario y Helguero que luego de unos años de estancia se dedican al comercio para de allí empezar a ocupar alcaldías y cargos burocráticos en la provincia que les permite finalmente ingresar al proceso lento pero seguro de la compra de tierras en el piedemonte andino entre Tambogrande y Salitral y vincularse con mujeres con rica dote matrimonial y patrimonio de tierras ocupados por vacas, chivos y mulas.

Para esto las órdenes religiosas también ya habían participado del reparto de tierras del Estado virreinal y desde la ciudad de Lima se ordena la realización de visitas y composiciones de tierras que fortalece a la familia Sojo-Fernandez de Paredes ligados a la elite limeña. En el corto plazo esta familia de la nobleza limeña monopoliza las mejores tierras en el valle de La Chira (Tangarará) y compra más tierras en Morropon y Tumbes. La posesión de su rango nobiliario no le impide dedicarse al comercio terrestre y marítimo; también al préstamo de dinero a los pequeños hacendados criollos e indígenas.

En la primera mitad del siglo XVIII se dedican al comercio de la cascarilla y del algodón. El negocio de las tinas con los jabones y las curtiembres y los cordobanes había sido abandonado para reemplazarlos por el cultivo del algodón y el engorde de ganado vacuno en los potreros y la venta de mulas que reproducían en los campos de Tangarará. Esta actividad pecuaria la realizaban con mano de obra negra esclava y liberta (César Espinoza 2019: 267-290)

La hacienda de Tangarará encuentra en la mano de obra tributaria de los pueblos indígenas circunvencinos y de los mestizos que laboran en la categoría de campesinos colonos la fuerza física laboral para asegurar sus ciclos productivos y de cosecha semestrales y anuales. De esta forma, los antecesores del marqués de Salinas van a expandir sus fronteras territoriales usando la fuerza de la ley virreinal pero también de las tropas militares que van a organizarse como los Dragones de Amotape y Querecotillo para intentar monopolizar todo el valle de La Chira. En este proyecto político se concentró don Francisco Xavier Fernandez de Paredes, el marqués de Salinas, a quien le tocó enfrentarse a los habitantes que habían formado el palenque de Querecotillo, una organización social de campesinos sin tierras que vivirán del comercio y del bandolerismo para después transitar en convertirse en una fuerza política para el proyecto liberal que impulsaba junto a otros hacendados y comerciantes criollos vinculados con Torre Tagle en Trujillo y don José de la Riva Agüero en la ciudad de Lima.

Ahora bien, antes de exponer algunos apuntes preliminares de la historia de la hacienda de Tangarará exponemos algunas proposiciones de trabajo sobre el contexto histórico de su formación y funcionamiento.

\section{Felipe II, los virreyes, los corregidores y el surgimiento de la propiedad privada rural y las "composiciones generales» de tierras en Perú y Piura desde 1595}

Pizarro llega a Tumbes y luego baja a Poechos y tiene una primera entrevista con un gobernador Ynga (Maizavilca) que administraba este valle y que al poco tiempo abandona la región tallán. Después intenta dialogar con los caciques tallanes, pero estos van a ser acusados de rebeldía y los elimina usando la hoguera y la espada. Luego moviliza a su tropa y los estaciona en el asiento de Tangarará, allí realiza una misa y una sesión de fundación de lo que va a comenzar a llamarse la ciudad de San Miguel de Nueva Castilla. Casi al terminar el año de 1532 se dirige hacia Olmos y Saña para luego empezar a subir a la sierra acompañado de tropas indígenas multiétnicas. Ha recibido noticias de que Atahualpa se encuentra en la sierra de Cajamarca.

Diego de Almagro llega por mar y se introduce a San Miguel recién a comienzos de $1533 .{ }^{20}$ Pizarro le encarga que apoye a Sebastián de Benalcazar a quien comisionó para que suba a Quito y pueda contener el ingreso de Pedro de Alvarado, gobernador de Guatemala, quien junto a una tropa de soldados españoles y cientos de indígenas estaba introducién-

20 Falta precisar la fecha ya que otros autores dicen que llegó a fines de noviembre de 1532 cuando ya se había realizado la fundación de San Miguel de Nueva Castilla. De allí sube a Cajamarca en abril de 1533 para después llegar al Cuzco. Finalmente, retorna a San Miguel de Tangarará en mayo de 1534. 
dose a una jurisdicción que no le correspondía. El acontecimiento político y militar asociado a estos dos líderes es la derrota de un gobernador Ynga, llamado Rumiñahui. Obtenida de esta victoria militar Diego de Almagro baja nuevamente a San Miguel (Tangarará) y con una nueva tropa y aliados indígenas sube y llega a Cajamarca en 14 de abril de 1533 y allí confirma la noticia de la captura de Atahualpa por las tropas de Pizarro en 16.11.1532. En esta ocasión lo acompañaron Hernando de Soto, Hernando Pizarro y dos intérpretes yungas Felipillo y Martinillo.

El primer dato sobre la apropiación y uso de la tierra es la presencia de Pizarro en Tangarará. Aquí ordena organizar un primer centro poblado ya que se siente protegido por la población tallán. Algunos documentos señalan que el sitio de la primera ocupación puede ser Illapa, cercano a Marcavelica, pero otros consideran que fue a un costado del actual pueblo de Tangarará, cerca de los restos de la casa-hacienda que ocupó a comienzos del siglo XIX el marqués de Salinas, don Francisco Xavier Fernández de Paredes. Otros cronistas lo vinculan a las tierras vecinas de Sojo y La Capullana, ubicados casi a orillas del rio La Chira.

La documentación notarial de los siglos XVI al XVIII señalan los límites de las tierras de la hacienda de Tangarará cuyas fronteras en dirección al mar llegaban a las tierras de la comunidad de Amotape y por el otro extremo a lo que ahora se llama tierras de Mallares. Lo cierto es que para todo el siglo XVII y comienzos del XVIII gobierna estas tierras la familia Sojo Cantoral. Una parte de las tierras de humedad sirve para el cultivo del maíz y del algodón, lo restante va a ser cercado para levantar potreros e invernas dedicados a la crianza y engorde de una variedad de ganado caprino y vacuno. La mano de obra proviene de los pueblos indígenas circunvecinos; un pequeño número son mitayos y yanaconas, la mayoría asentada son colonos campesinos indígenas y también parceleros libertos y negros esclavos que vigilan los negocios del hacendado.

La formación de la propiedad privada de la tierra: el sistema de tenencia y herencia de las tierras de Tangarará entre los siglos XVI-XVIII

El valle de La Chira permaneció casi semiabandonado durante el siglo XVI por la destrucción de los sis- temas de riego y la escasez de mano de obra indígena. En sus alrededores viven pequeños dueños de parcelas y potreros que habían designado las autoridades municipales de Piura a cambio de una pequeña renta. El despoblamiento de este territorio fue la consecuencia de la guerra de Pizarro contra los tallanes, pero también la continuación de la guerra entre los encomenderos y contra el rey Felipe II. La ocupación temporal lo realizan los indígenas organizados en el pueblo de Amotape y de Pariñas-Malacas que la utilizan todavía en este siglo en poca escala territorial debido a que el valle concentra muchos pantanos y lagunas a las que la gente no se introduce a finales del siglo XVI por la presencia de enfermedades palúdicas.

A continuación presentamos un conjunto de datos sobre los pleitos judiciales por las tierras de Tangarará entre los Sojo y familias indígenas tallanes. ${ }^{21}$

El expediente judicial que revisamos esta incompleto y muy deteriorado, sin embargo, se puede extraer un conjunto de datos y de información cualitativa que permite conocer el proceso de concentración de tierras por una familia española que se asienta en este valle en la condición de propietario privado de tierras.

Los escritos muestran las posiciones defendidas por el capitán Francisco de Sojo y un religioso, el licenciado Francisco Martínez de Palomar, quien actúa en la calidad de tenedor de bienes del indígena Juan Chunay. El expediente que se forma con los testimonios orales y los documentos que son prueba de la posesión de cada una de las partes ha viajado a la Real Audiencia de Lima y allí los jueces y Oidores ya han tomado una decisión para que el expediente viaje nuevamente a la ciudad de SM de Piura.

De tal forma que mediante un escrito don Francisco de Sojo solicita al corregidor de Piura que el expediente judicial sea trasladado nuevamente a la Real Audiencia de Lima para que pueda atenderse su petición. En esta ocasión, 21.11.1682 actúa de Escribano don Josef de Céspedes (f.2).

El representante del indígena, el licenciado Francisco Martínez de Palomar, presbítero y vecino

21 Archivo General de la Nación. 1679. Sección títulos de Propiedad. Legajo 7, Cuaderno 153, 102 folios. Títulos de las tierras y pastos de Tangarará... que el capitán Francisco de Soxo ganó en juicio al licenciado Francisco Martínez de Palomar, albacea y tenedor de bienes de Juan Chunay. 


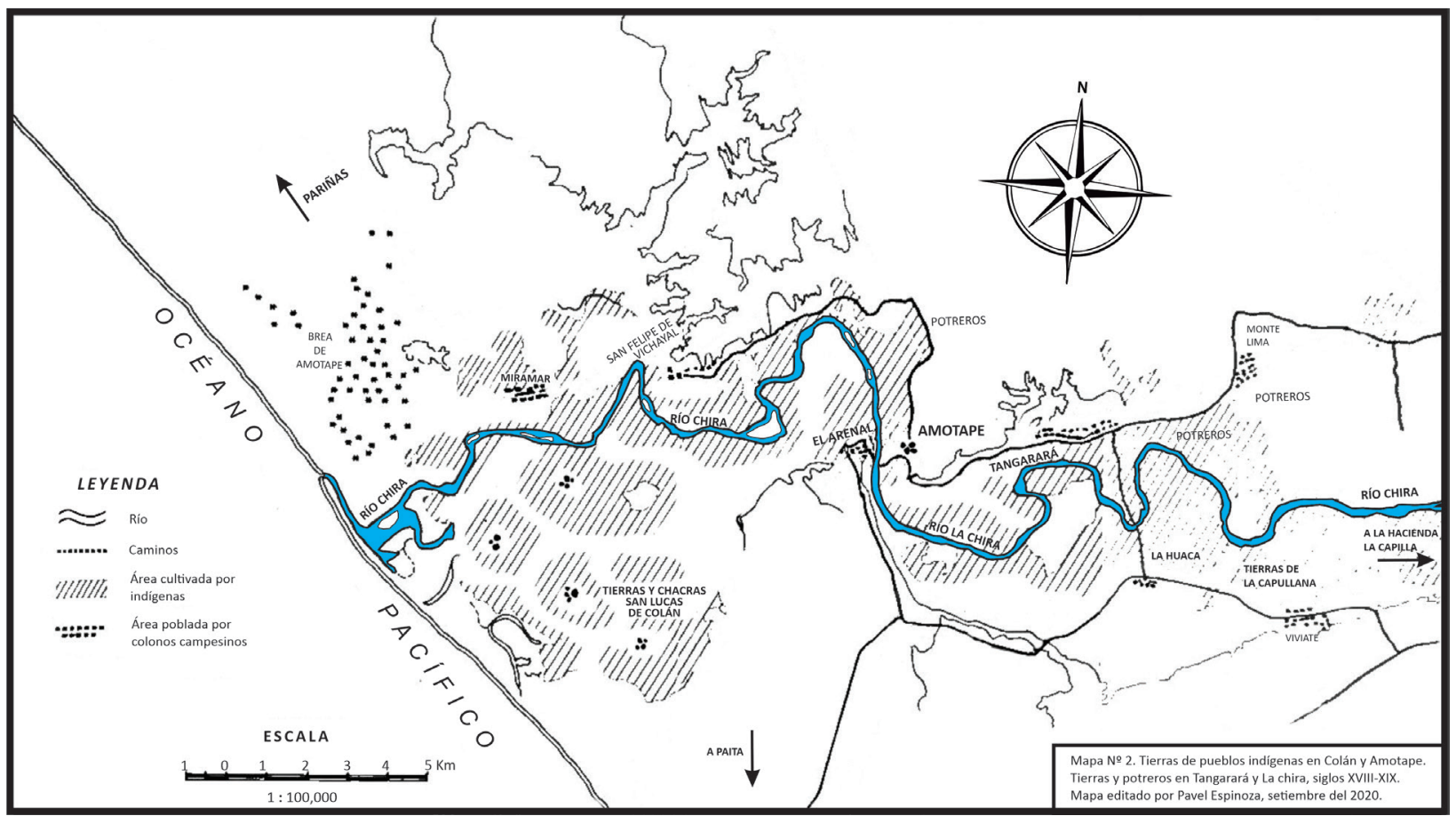

El valle de La Chira, la hacienda de Tangarará, Amotape y San Lucas de Colán, siglos XVI-XVIII.

de la ciudad de Piura señala que en la ciudad de Lima se presentó Francisco Gómez Ortiz, Procurador, a nombre del capitán Francisco de Soxo, de oficio regidor, juez y Fiel Ejecutor de la ciudad de SM de Piura.

Recuerda que en una ocasión anterior Sojo había presentado otro escrito de apelación y de nulidad de los autos contra los presentados por el corregidor de Piura y el Tesorero don Diego de Mata, juez nombrado para este proceso. La fecha de ingreso se registró en Los Reyes a 09.09.1681 (f.4v).

Sojo mantiene la sospecha de que esta vez el corregidor de Piura mantiene una alianza temporal con el religioso Francisco Martínez de Palomar para despojarle de una porción de tierras de labranza en el sitio de Tangarará.

En efecto, en SM de Piura, con fecha 21.11.1682, el escribano público y de Cabildo, don José de Céspedes informa que esta vez le entregó todo el expediente escrito al licenciado Francisco Martinez de Palomar, presbítero, y a Blas Francisco Gutiérrez de Salazar, quien en esta ocasión actuaba de Protector de Naturales, en nombre de Andrés Chaves y Andrés Acaro, ambos indígenas residentes en la ciudad de SM de Piura, quienes son los interesados en defender las tierras y que los autos judiciales prosigan (f.5).
En SM de Piura, en 05.07.1679, don Pedro Vasa Balles, caballero de la orden de Santiago, actúa de corregidor y justicia real. Don Francisco de Soxo, vecino de SM de Piura, informa en otro escrito que la provisión real enviada desde la ciudad de Lima no había sido obedecido por el presbítero Francisco Martínez de Palomar sobre el asunto de las tierras que disputan en el rio de La Chira (f.9v). Anota que esta vez no se ha cumplido con el proceso, la citación y las calidades que requiere este asunto y por tanto, solicita esta vez que se presenten los títulos para presentar el alegato necesario (f.9v-10).

Nuevamente el corregidor Vasa Balles ordena al licenciado Francisco Martínez para que use el terreno hasta que se realice la presentación de los títulos de propiedad de cada una de las partes. Acompaña el escrito una firma del escribano Andrés Marques de Gaceta (f.10).

Don Francisco de Soxo en 06.06.1679 recuerda que recibió la noticia de que el presbítero Francisco Martínez había tomado posesión de las tierras en disputa diciendo que gozaba de la calidad de albacea y tenedor de bienes del indígena Francisco Chunay. Señala que estas son unas tierras ubicadas casi al borde del rio de La Chira, y que Francisco Soxo las tiene en su posesión y propiedad. Añade que en esa ocasión 
se notificó a un "indio mi yanacona” para que se presente en SM de Piura a "dar razón conque orden estaba en el paraje de Marcabelica siento tierras mías", pidió, por tanto, que Chunay presente los títulos y sino que deje la posesión de las tierras judicializadas, y lo registre ante el presente escribano y que el presentará los suyos para que se determine la justicia de su reclamo (f.11).

El corregidor ordena que el albacea de los indios Francisco Martínez presente los títulos (f.12), agregando que ya el escribano le hizo la notificación correspondiente.

En otro escrito, de fecha 08.07.1679, se precisa que Juan Chunay y Juana Mayor, son indios tallanes que ya están muertos. El albacea nombrado es el cura Francisco Martínez, quien informa que el presentará los títulos de las tierras cuando así lo practique también don Francisco de Soxo (f.12v). En consecuencia, este solicita que el corregidor lo mantenga todavía en la posesión de estas tierras que gozan de la categoría de "tierras de humedad", y que en ellas sostiene a dos manadas de ganado menor (f.13v).

Después del gobierno del virrey don Francisco de Toledo en el último tercio del siglo XVI, se va a reconcentrar a la población indígena dispersa en dos microterritorios colindantes con la pequeña ciudadpuerto de San Francisco de la Buena Esperanza de Payta. La ciudad de San Miguel de Piura ocupa un pedazo de tierra agrícola a un costado del río Lengash, $y$ es desde esta pequeña urbe que varias comisiones del Estado virreinal van a practicar tres Visitas y composiciones de tierras (1595, 1645 y 1714). Esta nueva distribución de tierras desde el Estado virreinal y sus corregidores van a organizar con este mecanismo un patrón de tierras de Haciendas y de estancias ganaderas a partir del siglo XVII, diferenciándose las tierras de frontera y de humedad en lo que ahora abarca las tierras de Amotape-Colán, microespacio ubicado casi en la desembocadura del rio La Chira y a orillas del mar, y el piedemonte andino de Poechos-Tambogrande.

Con el virrey Toledo se había reconocido a los grupos y pueblos indígenas dispersos entre Tumbes y Parińas y reconcentrado a la población nativa sobreviviente en Malacas (Talara) y Amotape, asignándoles pedazos de tierras con ojos de agua para asegurar los caminos y puentes que permitían la comunicación con la bahía y playas de Tumbes. Alrededor de Amotape se privatizan las tierras de Parińas y Máncora para en el siglo XVIII convertirse en tierras de hacienda o gran propiedad que van a administrar los Betlemitas y dedicarlo a la crianza y engorde de ganado caprino y porcino que se consumían en las tinas y curtiembres artesanales que empezaron a levantarse a orillas del rio La Chira. Estos negocios sumados a la crianza de las mulas y de la explotación del algarrobo, del maíz y del algodón provocan estos litigios judiciales que administra el corregidor de Piura y que no puede contener las negociaciones y los expedientes van a ser revisados y procesados en la Real Audiencia de Lima y otros llegaran incluso al Consejo de Indias, España.

El corregidor y el escribano desde la ciudad de SM Piura en 19.07.1679 notifican a las partes en pugna sobre las resoluciones de las autoridades virreinales. En esta ocasión se encarga entregar las notificaciones a don Juan Benavente y Chávez. En esta fecha, don Francisco Soxo presenta la Real Provisión que le otorgó la Real Audiencia de Lima en la que le ampara la posesión de los sitios y las tierras de Tangarará, una estancia de la que ya tiene posesión por más de veinte años (1659), y que en esa ocasión cumplió con ejecutar el mandato real don Antonio Lasso y que también lo defendió ante las pretensiones practicadas por el religioso Francisco Martínez de Palomar. Advierte, que este último ahora está gestionando que el primero que exhiba los títulos sea Sojo (15), una posición que ahora "inquieta y perturba la gente de mi hacienda" (f.15v). De tal forma, que él ahora solicita que se le otorgue el amparo de la autoridad pues mantiene una posesión antigua y que también Francisco Martínez cumpla con exhibir los títulos correspondientes.

En otro escrito registrado en SM de Piura en 13.07.1679, el corregidor informa que Francisco Soxo pidió que el escribano le proporcione una copia y el testimonio de sus títulos de las tierras que posee en propiedad (f.17).

Los documentos que se registran en este expediente están fechados en SM de Piura en 20.05.1665. Uno de ellos está firmado por don Antonio Laso de la Vega y Córdoba, teniente de corregidor, señala que don Francisco Soxo tiene la "posesión de sitios y pastos y montes de la estancia de Tangarará, en el río de La Chira" (f.17v). En otro escrito presenta una copia de los títulos y una provisión real de amparo a esta propiedad; y ahora solicita que se le ampare la posesión real, así como antes la tuvieron el capi- 
tán Gaspar Troche de Buitrago y el capitán Hernando Troche de Buitrago, su hijo, y el capitán Juan de la Herrera, su yerno y tíos de doña Catalina Cornejo de Cantoral, mujer de Francisco de Soxo; pues afirma que ya tienen la posesión de esta propiedad por más de 70 ańos. Es decir, desde aproximadamente el año de 1595.

Este expediente judicial contiene muchos escritos de ambas partes que muestran autorizaciones de las autoridades de Piura y Lima, pero también el uso de la fuerza para mantener ocupadas y en uso algunas secciones de la propiedad rural en pugna.

En uno de los escritos se describe la ocupación de estas tierras por Juan Fernández, que lo hizo conduciendo una cantidad de su ganado menor. Frente a este accionar intervienen las autoridades locales, pero nada pudieron hacerlo para desalojarlo pues el autor se negó a practicarlo (f.18). Y ahora con la finalidad de conseguirlo se usa una Real Provisión para que el corregidor pueda sacarlo. Sojo recuerda en otro escrito que esta tierra la compró a Su Majestad y que la propiedad está protegida por una Real Provisión. Pide entonces que la desocupen y dejen libres Juan Fernández y otras personas que la han tomado por la fuerza ocupándola con su ganado y que esta vez intervenga el teniente del pueblo de Amotape (f.19).

Avanzando el proceso, en otro escrito se registra que el escribano de SM de Piura, Agustín Bautista Flores ordena la entrega de una copia de la Real Provisión (f.19). Y en respuesta, esta vez se adjunta una copia de la provisión que empieza señalando: "Don Felipe", y en la que ordena que el corregidor de Piura y su lugarteniente cumplan la orden, agregando que Francisco Soxo presentó una petición escrita y que lo tramita a su nombre don Miguel de Medina. Se señala que Soxo mantiene unos sitios de pastos y una estancia compuesto a SM en una "Composición" de tierras, y que los "dichos pastos y sitios se llaman "La Matanssa y La Punta hasta el cerro de Tangarará y otros en el sitio de La Chira desde frontero de sitio de Jibito ante la Capullana de una y otra banda, y los demás linderos expresados en dichos títulos" (f.20v); y que estando en posesión de estos más de sesenta años, ordena que el corregidor no consienta a nadie en su posesión” (f.21).

Esta documentación escrita adjunta al expediente judicial parece que llega a la Real Audiencia de Lima y allí en Los Reyes, en 15.04.1665, los Oidores y jueces ordenan que se despache una copia de esta provisión de amparo (f.21v) para la protección de los bienes que posee Francisco Soxo.

Nuevamente, en SM de Piura, en 20.05.1665, se presenta a don Antonio Lasso de la Vega y Cordoba, teniente de Corregidor de Piura, la Real Provisión gestionada por Francisco Soxo, y esta vez se indica que el teniente de Amotape lo cumpla "en las tierras y sitios de Tangarará que corre desde frontero de Jibito de la otra banda hasta la Capullana de La Chira, y de esta banda, desde el bebedero de Yutussina hasta frontero de la Capullana de La Chira, según consta de la posesión que se le dio por Pedro Pérez de las Marińas, a quien la cometió su merced y el dicho Teniente de el dicho partido de Amotape, ayudante Juan Benites" y que este lo amparará en la dicha posesión de dichas tierras y sitios y que lanzará a cualquier persona que la ocupara, demoliéndoles los ranchos y corrales (f.21v).

En consecuencia y para dar cumplimiento a estas órdenes, las autoridades de Piura se reúnen en el sitio de Tangarará, en la hacienda del capitán don Francisco de Soxo, en 8.10.1666, y a la que asisten el ayudante don Juan Benites Gallardo, teniente de corregidor de Amotape, por auto de don Antonio Laso de la Bega, justicia mayor, y se realiza la construcción de otro documento que amparo los derechos de Francisco de Soxo de los sitios, pastos y tierras de la estancia de Tangarará. Se verifica entonces que estos forman parte de los autos y títulos que despacha la Real Audiencia de Lima y que registra las fronteras siguientes: "desde la dicha estancia de Tangarará, el río arriba hasta la Punta de Marcavelica, donde tiene un corral en unos paredones, y en él una manada de ganado cabrío y ovejuno, y desde la dicha estancia, río abajo hasta la Capullana de La Chira, donde junto al río tiene otro corral con otra manada que guarda un indio de Catacaos llamado Lorenzo Naquicha, y el dicho corral está donde llaman Guan, y junto al dicho sitio siembra un indio llamado Balentín en tierras del dicho capitán, y de su consentimiento le quedó en ellas, y todo lo referido de la otra banda del dicho río, y de esta banda le ampare desde el bebedero de Yutussima hasta la quebrada de Macacará, río abajo, así en la una como en la otra, en todos los montes, tierras y pastos, que comprehenden los linderos expresados en los títulos y provisión, y que sin contradicción de persona alguna, y lo firmó en dicho 
día de 8.10.1666 (f. 25v-26). Terminado este acto de revisita local se pasó a devolver los títulos y la provisión real al capitán don Francisco de Soxo.

En otro documento escrito anexo al expediente se encuentra anotado lo siguiente "Yo Lucas Garcia Serrano, escribano de SM y de la Visita que se realiza en Piura; el capitán García de Paredes y Ulloa, informa que para la "perpetuación, venta, composición de tierras" en que se da fe de que don Gaspar Troche de Buitrago, vecino de Piura, hizo la composición de una estancia de corrales en 12.09.1595 (f.27).

Precisa este escrito que en esta ocasión el Visitador García de Paredes ordenó mediante un pregón público que los vecinos de la ciudad de Piura presentaran los títulos de sus propiedades rurales y urbanos y que compusieran las chacras, viñas, tierras de pan llevar, huertas, estancias y otros heredamientos (f.27) para avanzar en el proceso de la venta de las tierras del Estado virreinal.

Concluye este representante virreinal señalando que se trata de una "estancia y corrales de ganado" que tiene y posee Sojo en Tangarará, y en la que tiene al presente 700 cabezas de ganado menudo, más unas casas en el puerto de Payta, y que el visitador lo admitió en este acto fechado en SM de Piura en 13.09 .1595 (f.28).

\section{Hacienda y estancia de Tangarará, tierras, indios mitayos y negros esclavos 1690-1838}

En la ciudad de Piura, en 26.01.1838, Don Pedro Pablo Ruesta informa que se presentó como vecino postor en el remate de la hacienda de "La Soledad", que forma parte de los bienes que dejó el finado D. Manuel Benites. Mediante este escrito solicita el acceso a los documentos presentados por D. Manuel Ruiz de Aranda, a nombre de la viuda y albacea Doña Juana Carpio, sobre la situación de un "algodonal plantado por su parte en dicho fundo, se extiende fuera de remate por haberse creado después de la tasación". En este escrito se señala que en el proceso judicial no se ha precisado la existencia de dos propiedades, uno tangible y el otro intangible; "uno del suelo, que lo ha hecho suyo en fuerza del remate y el otro del algodón plantado en este mismo suelo, lo que impide al primero el uso libre de su propiedad" (f.1).22

Otro personaje interesado en esta porción de tierras de orilla y de labranza de algodonales es don Francisco Xavier Fernandez de Paredes, coronel del Ejército, quien mediante otro escrito señala que se está "subastando el potrero y tierras de "La Soledad", cita en el sitio del rio de La Chira, llamadas antiguamente Tangarará de esta banda" (f.4). Precisa que tiene una hipoteca cargada a su favor por 1,500 pesos de principal y los réditos acumulados de dos años y dos meses hasta el 27.06.1838. Termina su escrito manifestando que su propiedad lo posee desde que lo adquirió su cuarto abuelo, D. Francisco de Sojo (f.4).

En este expediente intervienen varias personas. Primero los postores a la hacienda D. Pedro Pablo Ruesta, Higinio Gómez y D. Manuel Reyes. También doña Josefa Benites coheredera casada con D. Juan Taboada y D. Pio Benites coheredero. Procesan el expediente D. Santiago de León, tutor fiscal de menores y D. Manuel Ruiz de Aranda, procurador.

En 27.06.1838 se realizó el acto de remate de una casa y el potrero de "La Soledad" vigilado por el juez de Letras de la provincia Litoral de Piura, Dr. D. Gaspar Carrasco. Se encuentran presentes el Procurador D. Manuel Ruiz de Aranda en calidad de apoderado de dońa Juana del Carpio y viuda albacea de D. Manuel Benites, finado. También asiste el Síndico Procurador General Dr. Santiago de León, tutor fiscal. D. Juan Antonio Taboada, esposo de dońa Josefa Benites, coheredero y otros ciudadanos más presentes.

La casa está ubicada al final de la calle del Playón, en los barrios de abajo, a mitad de cuadra que hace frente a la de la finada Estefanía Machado. Mide por la frontera $273 / 4$ varas y de fondo $551 / 2$ varas. Los linderos son: por el costado de arriba con la casa de Tomasa Sojo; por el costado de abajo con la casa de Manuel Paz; por las espaldas con unos ranchos que caen a la otra calle. El valor de esta propiedad es de 2,890.7 pesos y en esa oportunidad se ofrece la cantidad de 1,500 pesos.

22 ARP. 1838. JPI. CC. Caja 39, Expediente 773. Autos de la causa mortuoria del finado D. Manuel Benites fechado en 26.06.1838. Escribano Público D. Manuel Jose de la Vega. Expediente en la que se procesa la venta y remate de una casa en la ciudad de SM de Piura y de un potrero ubicado colindante a la hacienda de Tangarará. 
De otra parte, el potrero de "La Soledad" se informa que está ubicada en las orillas del rio de La Chira, de esta banda; sus linderos son: costado, con el potrero de Macacará; por el otro con tierras de "Monte Sojo", del dueño de la hacienda de Tangarará. Fue valorizada en 3,800 pesos el casco, los cercos y la casa construida. En el remate se ofrece la cantidad de 2,683.2 pesos.

Se advierte que la casa tiene un censo cargado de 1,100 pesos a favor de las monjas del Monasterio de la Concepción de Loja. Esta se distribuye en ambas propiedades: la casa en 550 pesos a un 3\% y el potrero 550 pesos a un $2 \%$. También se señala que en este remate queda excluido el "plantío de algodón" por ser una propiedad de la viuda albacea y también de que Fernandez de Paredes presentó un recurso escrito en la que señala que este potrero "La Soledad" estaba ligado a él por una hipoteca cargada a su favor por la cantidad de 1,500 pesos de principal y sus réditos acumulados que le adeudaban. Agrega que sus ascendientes le cedieron también sus servidumbres perpetuas a favor de D. Pio Benites coheredero de D. Manuel Benites, siempre que caiga el remate en su favor. Al final se vendió todo por la cantidad de 4,670 pesos y el reconocimiento de un censo de 550 pesos por Ruesta para D. Ignacio Checa. La casa en esta ocasión fue rematada a D. Manuel Reyes en 1,500 pesos y a favor de dońa Juana del Carpio viuda de Manuel Benites. Fue la ocasión del reclamo presentado por D. Pio Benites sobre el potrero "La Soledad" (f.12). A dońa Juana del Carpio se le informa que entre los bienes mortuorios encontrados en el puerto de Payta correspondientes al finado D. Manuel Benites, se encontraron otras tres casas, y que una se la dio Benites a doña Juana del Carpio e hijos (f.16) y también otra casa en la calle La Libertad por el valor de 884 pesos y otra en la calle del Pozo valorizada en 1,214.2 pesos. El proceso legal y la valorización se realizaron entre junio y agosto del año de 1838 .

\section{Conclusiones preliminares}

La revisión de la literatura producida y la pesquisa y el trabajo con un material de archivo preliminar nos ha permitido examinar la costa norte del Perú antes y después de 1532 para empezar a descifrar los cambios y las permanencias de la sociedad tallán y la forma- ción de un sistema agrario colonial que va constituyéndose gradualmente enfrentando una grave crisis demográfica, los ciclos de las alteraciones climáticas y las agresiones externas de los británicos ansiosos por conseguir una parte de la plata y el oro que circulan por los caminos del mar y el Qapac Nan impidiendo su acumulación en la pequeña urbe de San Miguel de Piura que para sobrevivir se moviliza entre el piedemonte costero y las orillas del mar para finalmente en 1588 asentarse entre los médanos y las orillas del río Lengash vigilados por los labriegos y pastores indígenas de Catacaos, Sechura, Olmos y mitimaes cañaris.

En este escrito se construye una serie de reflexiones sobre la racionalidad, de los pueblos y las sociedades prehispánicas (tallanes e Yngas) respecto a la visión y el uso que daban a la tierra. En Tangarará y Pabur los terrenos agrícolas son resultado de una práctica cultural diferenciada porque en la primera abunda el agua, y en la segunda, solo dispone del recurso hídrico de manera temporal. En ambos espacios se utilizan varias tecnologías tangibles e intangibles que van a permitir manejar sus fronteras territoriales especializando microespacios o "tierras de humedad" para el cultivo del maíz y el algodón, de los granos y las hortalizas, pero también de la construcción de unidades complementarias para la crianza y la reproducción del ganado camélido. En ambos espacios se usa el terreno para habitar y desarrollar sus formas de subsistencia, pero también la generación de un excedente que se apropian los Yngas para fortalecer su aparato estatal y militar.

La otra experiencia social que examinamos es el proceso que condujo al establecimiento de una realidad colonial en un territorio que durante el siglo XVI va a ser usado como entrada estratégica para la guerra de Espańa contra los Yngas. De tal forma, que en la segunda mitad del siglo XVI se afirmará la instalación y funcionamiento de una ciudad como San Miguel de Piura y que el Estado virreinal Habsburgo lo utilizará para darle forma al sistema agrario de haciendas y pueblos indígenas que permitirá la reproducción del corregimiento de Piura y el sometimiento de su población a la política que impondrá Felipe II con sus virreyes, encomenderos y corregidores.

Es al interior de este contexto histórico que empieza a emerger un nuevo manejo de la tierra por un puñado de propietarios privados que utilizando el poder del cabildo y del capital acumulado final- 
mente se apoderaran de las mejores tierras y pastos en Tangarará y el valle de La Chira.

En buena cuenta, este primer escrito pretende asociar este conjunto de variables para demostrar cómo es que la población tallán impone su lógica de manejo de la tierra y una variedad de formas de producción agraria en espacios con muchas dificultades en el manejo del recurso agua y de los bosques de algarrobo. Paralelamente también marcha de manera incontenible la privatización de la tierra y la formación de la hacienda de Tangarará sin caer en el extremismo de imponer el peonaje asalariado y por el contrario utilizar los sistemas de trabajo manual y comunitario del mundo indígena, que bajo el formato del colonato campesino, son propicias para la instauración y reproducción de mecanismos de explotación a gran escala de la fuerza de trabajo por parte del nuevo poder coloniales hispano en el siglo XVI y su multiplicación y permanencia en los siglos venideros.

Como señalamos líneas arriba, la historia no es lineal, por el contrario, se asocian varias historias con dinámicas diferentes, pero también con rupturas que no puede manejar la sociedad humana como son los prolongados años secos o las imprevistas lluvias e inundaciones que van a categorizar a la ciudad de Piura como una urbe al volante y a los labradores indígenas como gente dispersa en varios tipos de paisaje territorial.

Un asunto que buscamos precisar es este tránsito del mundo tallán-inca que vive de la agricultura a otro tiempo virreinal en la que se prioriza la estancia ganadera y los negocios con los jabones y los cordobanes. Los españoles y los indígenas buscaron siempre asentarse en territorios con agua y con la disponibilidad de los bosques de algarrobo y el hualtaco. Estamos entonces, frente a una tierra que Pizarro y sus conquistadores pueden manejarlo, ya que está representado por un paisaje que cambia y se modifica, y que le permite tener la seguridad de disponer de una base material para su proyecto político y militar contra los Incas.

Pero conforme avanza el tiempo y la guerra, este paisaje se transforma porque la población tallán va a ser movilizado a otros espacios y muchos van a morir contrayéndose el patrón demográfico regional. Con la imposición de la estancia ganadera y de las haciendas, este paisaje se transforma, sin embargo, la tierra permanece constante, inalterada, las tierras de orillas o de "humedad" van a ser monopolizadas por los blancos y los indígenas yungas van a ser ubicados entre los médanos y los jaguayes, para en poco tiempo habilitarlos mediante el trabajo comunitario y el manejo de sus conocimientos intangibles, un accionar que muestra como persistió una vasta fuerza social para llegar a ingresar incluso al ciclo mercantil todavía de manera preliminar. La novedad es que este tipo de accionar que trabajó el terreno (economías de parcelas) lo hará sin arrasar también el paisaje buscando conservarlo junto a los bosques y una vegetación de zonas áridas y subtropicales. Todo un movimiento contrario a lo que ocurrió con la hacienda de Tangarará que en su afán de expansión territorial arrasó con la tierra imponiendo una supuesta revolución radical de homogeneización que va a provocar la modificación de un ambiente y un paisaje que angustia la vida de los dueños, los labradores indígenas $\mathrm{y}$ afrodescendientes.

\section{Bibliografia}

Albornoz Neyra, Laura (2015). Los ingleses en la actividad socioeconómica de Piura durante la segunda mitad del siglo XIX. Maestría en Educación con Mención en Historia. UDEP, Piura, Perú.

Aldana Rivera, Susana (2018). Despertar el alma nacional. Región y nación en la construcción de la nación peruana. Tesis Doctor en Ciencias Sociales (Historia), UPG. Facultad de Ciencias Sociales. UNMSM, Lima, Perú.

Araujo, Luis Rafael (2019). Perigo que vem do mar: o ataque de Thomas Cavendish ao Espíritu Santo Colonial. En História em Rede, 24 Augusto.

https://medium.com/@historiaemrede/perigo-quevem-do-mar-o-ataque-de-thomas-cavendish-aoesp\%C3\%ADrito-santo-colonial-88e 471 cf8f3f. Consultado en 12.10.2020.

Astuhuamán González, César y Fernando Vela Cossío (2010). «Evaluación del potencial arqueológico del yacimiento y propuesta de investigación»; pp. 113-116. En: San Miguel de Piura, primera fundación española en el Perú. Informe de bases y avance del Plan Director del sitio arqueológico de Piura la Vieja, La Matanza (Piura, Perú). Madrid, Mairea Libros.

Astuhuamán Gonzáles, César (1999). Los Incas en el Extremo Noroeste del Perú. Comunidad; TierraHombre-Identidad 3: 38-44. Piura. 
Bonialian, Mariano (2019). «Panamá, Perú y el universo económico del Pacífico en la temprana globalización, 1580-1640». En: Nuevo Mundo Mundos Nuevos. https://doi.org/10.4000/nuevomundo.76620. Consultado en 12.12.20.

Burneo, María Luisa (2016). Transformaciones en el gobierno del espacio comunal: decisiones y dinámicas políticas en torno a los usos de la tierra y la extracción de recursos en el caso de la comunidad de San Lucas de Colán. SEPIA. Perú: El problema agrario en debate, $\mathrm{N}^{\circ} 16$, pp. 327-385. https://sepia.org.pe/wp-content/ uploads/2018/07/sepia-xvi-Arequipa-2016.pdf

Burneo, María Luisa y Huamán, A. (2013). Lógicas privadas y lógicas locales, una mirada a la presencia de las industrias extractivas desde las historias comunales. Politai, 4(6), 75-87.

http://revistas.pucp.edu.pe/index.php/politai/article/ view/14115. Consultado en 05.10.2020

Caillavet, Chantal (2000). Etnias del Norte. Etnohistoria e historia del Ecuador. Institut français d'études andines, Abya Yala, Casa de Velázquez. Colección Travaux de l'IFEA N ${ }^{\circ}$ 106, Lima, Perú. https://books.openedition. org/ifea/2870. Consultado 08.10.2020.

Camino, Lupe (1982). Los que vencieron al tiempo: Simbilá, costa Norte perfil etnográfico de un centro alfarero. Edic. CIPCA, Piura.

Cornejo, Raúl Estuardo (2007). El Alma de Piura. Elogio a un sentimiento. Editorial San Marcos, Lima, Perú.

Correa Gutiérrez, Yanina (2001). «La participación de Piura la Vieja en los primeros ańos de la conquista"; pp. 13-22 y 53-105. En: Conferencias y artículos. San Miguel de Piura. Primera fundación española en el Perú. Madrid: Dossat.

Costa Vigo, Luis M. (2017). Por no yr tan solo. Redes clientelares y dinámicas de poder en el virreinato del Perú: el caso del gobierno del virrey conde del Villar, 1585-1590; pp. 22-39. En Parientes, criados y allegados: los vínculos personales en el mundo virreinal peruano. Instituto Riva-Agüero. Lima.

http://ira.pucp.edu.pe/libreria/publicaciones/parientes-criados-y-allegados-los-vinculos-personales-en-elmundo-virreinal-peruano/

Costa Vigo, Luis M. (2016). ¿Prácticas corruptas o relaciones de patronazgo? Patrimonialismo y la naturaleza y características del sistema político en el Perú en el siglo XVI, durante el gobierno del Virrey Fernando de Torres y Portugal, Conde del Villar (1585-1590). En Dádivas, dones y dineros. Aportes a una nueva historia de la corrupción en América Latina desde el imperio español a la modernidad. (pp. 27-55). Frankfurt. Vervuert. http://www.iberoamericana-vervuert.es/FichaLibro. aspx?P1=115303.

Cruz Villegas, Jacobo (1982). Catac Ccaos: origen y evolución histórica de Catacaos. Edic. CIPCA, Piura, Perú.

Del Busto Duthurburu, José Antonio (2017). Túpac Yupanqui el resplandeciente. Tomo I. El conquistador. Tomo II. El gobernante. Piura, Universidad de Piura, Perú.

Del Busto Duthurburu, José Antonio (1969). Dos personajes de la conquista del Perú. Editorial Universitaria, Lima, Perú.

Diaz Maldonado, Carolina (2013). La gestión del riesgo en la presencia de eventos socio-naturales. Caso: lluvias torrenciales en Piura, 1997-1998. Tesis Magíster Sociología de las Organizaciones. UPG. Facultad de Ciencias Sociales, UNMSM, Lima, Perú.

Diez Hurtado, Alejandro (1987). Pueblos y caciques de Piura, siglos XVI y XVII. Edic. CIPCA, Piura, Perú. 1989. Historia comunal y organización religiosa, integración social en la comunidad de Sechura: siglo XVI al XX. PUCP, Facultad de Ciencias Sociales. Tesis Licenciatura en Antropología, Lima, Perú. 2006. Los problemas del poder: política local y gobierno en las reducciones de la costa de Piura, siglo XVII. En: Anthropológica, V.24 N 24; pp. 107-127. Lima, Perú. 2017. Propiedad y territorio como (diferentes) bienes comunes. El caso de las tierras de comunidades en la costa norte peruana. Eutopía, (11), 17-39.

https://www.doi.org/10.17141/eutopia.11.2017.2851. Consultado en 07.11.2020.

Domínguez Morante, Zózimo (2004-2007). La conquista española y el cambio socio-cultural en el pueblo tallán. En: Contraste, revista de Historia, $\mathrm{N}^{\circ} 13$, Perú.

Echeandia Valladares, Juan y Renate Wisbar (1990). Los ceramistas de Piura. Lima: Seminario de Historia Rural Andina, UNMSM.

Elías Lequernaque, Pavel (2004). "El Corregimiento de Piura en tiempos de la Casa de Austria"; pp. 211-269. En: Del Busto, José A. Historia de Piura. UDEP, Perú.

Elías Lequernaque, Pavel (2004a). Los señores resisten: los caciques de Catacaos y sus estrategias de actuación y adaptación en la sociedad piurana del siglo XVII. Tesis de Maestría en Estudios de la Cultura. Mención Historia Andina. Universidad Andina Simón Bolívar, Ecuador.

Espinoza Claudio, César (2018). Joaquín de Helguero y el pensamiento económico borbónico en Piura a co- 
mienzos del siglo XIX. Investigaciones Sociales, $\mathrm{N}^{\circ} 38$; 107-126. IIHS-UNMSM, Lima, Perú. https://doi. org/10.15381/is.v21i38.14220

Espinoza Claudio, César (2013). Historia regional e historia de la tierra. Anotaciones sobre el valle de La Chira, San Lucas de Colán y Amotape, Siglos XVIIIXX; pp. 339-368. En: Arqueología y Sociedad, No26, UNMSM, Lima, Perú.

Espinoza Claudio, César (2005). La lucha por el algodón en las tierras tropicales de Piura: la comunidad indígena de Catacaos y su incorporación subordinada a la economía regional colonial y republicana: XVI-XIX. Investigaciones Sociales, No 14, pp. 235-268.

Espinoza Claudio, César (1999). Sociedad indígena, tierra y curacazgos yungas en la región de Piura, siglos XVIXVIII. Catacaos y los desafios de la naturaleza, 15321732. Tesis de Magíster en Historia, PUCP, Lima.

Espinoza Soriano, Waldemar (2006). La Etnia Guayacundo en Ayabaca, Huancabamba y Caxas (Siglos $X V-X V I)$. Fondo Editorial del Pedagógico San Marcos, Lima.

Espinoza Soriano, Waldemar (1989). Los Guayacundos de Caxas y la sierra piurana, siglos $X V y$ XVI. Edic. CIPCA e IFEA, Piura, Perú.

Fernández Villegas, Oswaldo (1988). Curacazgos de la costa norte: Piura; p. 45-47. En: Boletín de Lima, $\mathrm{N}^{\circ}$ 60, noviembre. Lima, Perú.

Fernández Villegas, Oswaldo (1998). Conflictos por el poder en Colán, siglos XVII-XVIII. Cámara de Comercio y Producción de Piura, Perú.

Franco Temple, Eduardo (1981). Grupo cataquense y ritual en la fiesta de Semana Santa. Tesis de Bachiller, Programa Académico de Ciencias Sociales. PUCP, Lima, Perú.

Glave, Luis Miguel (1993). La Puerta del Perú: Paita y el extremo norte costeńo, 1600-1615; pp. 497-519. En: Boletin del Instituto Francés de Estudios Andinos, № 22 (2), Lima, Perú.

Glave, Luis Miguel (1991). El puerto de Paita y la costa norteña en la historia regional de Piura; pp. 501-509. En: Boletín del Instituto Francés de Estudios Andinos, $\mathrm{N}^{\circ}$ 20 (2), Lima, Perú.

Gnerre, Maurrizio (2003). José de Acosta y la sombra de Felipillo. Las raíces sociolinguisticas y retoricas del rechazo de los intérpretes; pp. 137-155. En: Laura Laurencih-Minelli y Paulina Numhauser Bar-Magen (Editoras). El Silencio protagonista. El primer siglo jesuita en el virreinato del Perú 1567-1667. Actas del
Simposio. Hist-11: "El primer siglo jesuita en el virreinato del Perú". 51 Congreso Internacional de Americanistas, Santiago de Chile, 17-18 de julio.

Guzman Palomino, Luis (et al.) (1996). Tambogrande y la historia de Piura en el siglo XVI. Centro de Estudios Histórico-Militares del Perú y Municipalidad distrital de Tambogrande, Piura, Perú.

Hocquenghen, Anne Marie; Zaida Lanning y Pierre Gondard (1999). Contribución al conocimiento de una zona de encuentro entre los Andes ecuatorianos y peruanos. Centro Nacional de Investigación Científica (CNRS); Instituto Francés de Estudios Andinos (IFEA); Instituto de Investigación para el Desarrollo (IRD).

Hocquenghen, Anne Marie (1993). El camino de Pizarro en Piura. En: INC PIURA-UNP 1993 Semana identidad cultural. Ponencias.

Hocquenghen, Anne Marie (1991). Frontera entre "áreas culturales" nor y centroandinas en los valles y la costa del extremo norte peruano". BIFEA 20 (2), pp. 309348, Lima, Perú.

Hocquenghen, Anne Marie (1994). Los españoles en los caminos del norte del Perú en 1532; pp. 1-67. En: Boletín del Instituto Francés de Estudios Andinos, $\mathrm{N}^{\circ} 23$, Lima, Perú.

Hocquenghen, Anne Marie (1998). Para vencer la muerte. Lima: Centro Nacional de la Investigación CientíficaInstituto Francés de Estudios Andinos-Instituto de la Naturaleza y el Conocimiento Ambiental Humano.

Hocquenghen, Anne Marie (2004). ¿Una posible macro región binacional andina? En: Hacia la elaboración de una imagen compartida de la región sur; pp. 23-54. Memorias del Seminario Taller. Ediciones Abya-Yala, Quito, Ecuador y Universidad Nacional de Loja, Ecuador.

Huamán Tejo, Alejandra Estefanía (2017). Tierras en pugna: cambios en la tenencia y el valor de la tierra comunal frente a la expansión del agronegocio del etanol en el valle del Chira, Piura. El caso de la comunidad campesina San Lucas de Colán. Tesis Licenciatura Antropología. PUCP, Facultad de Ciencias Sociales. Mención: Antropología, Lima, Perú.

Huertas Vallejos, Lorenzo (1991). "Perturbaciones étnicas en Piura". En: Boletin del Instituto Francés de Estudios Andinos, Tomo 20 (2); pp. 489-500, Lima, Perú. 
Huertas Vallejos, Lorenzo (1997). Cronología y tipología de los centros poblados de la región de Piura. En: Arqueología, antropología e historia en los Andes: Homenaje a Maria Rostworowski Lima: Instituto de estudios peruanos-IEP: Banco central de reserva del Perú-BCRP, 1997 p. 471-486, Lima, Perú.

Huertas Vallejos, Lorenzo (2009). Injurias del tiempo: desastres naturales en la historia del Perú. Lima: Universidad Ricardo Palma. Editorial Universitaria.

Jaramillo Arango, Antonio (2019). Navegación indígena en el puerto de Paita. Abasto y contrabando. BIFEA, № 48(1), pp. 39-55, Lima, Perú.

Johnstone, Christian (1844). Lives and voyages of Drake, Cavendish, and Dampier. Including an introductory view of the earlier discoveries in the South Sea, and the history of the Bucaniers. New York, USA.

LunA, Pablo (2013). Latifundia, haciendas et landgrabbing, en perspective historique. En: Revue HISTOIRES (S) de l'Amérique latine. Vol.8, pp. 1-8, París. URI: http://www.hisal.org/revue/article/Luna2013-8b. Consultado en 15.10.2020.

Moya Espinoza, Reynaldo (1994). Breve historia de Piura: la conquista. CYDES, Concejo Provincial de Piura. Colección Sec, Piura, Perú.

Martin Rubio, María del Carmen (2014). Francisco Pizarro. El hombre desconocido. Ediciones Nobel S.A., Asturias, España.

Martos, Néstor (1958). «De Tangarará al Chilcal: fundaciones y traslados de la ciudad de San Miguel de Piura»; pp. 158-166. En: León Saldivar, Rómulo, comp. Prosistas piuranos. Imprenta Minerva, Lima, Perú.

Mira Caballos, Esteban (2018). Francisco Pizarro. Una nueva visión de la conquista del Perú. Barcelona: Crítica.

Montoya Guzmán, Juan (2005). Un cronista por la Gobernación de Popayán: Cieza de León y su Crónica del Perú. pp.133-162. En: Revista Historia y Sociedad, $\mathrm{N}^{\circ} 11$, FCHE-UN, Facultad de Ciencias Humanas y Económicas, Escuela de Historia, Universidad Nacional de Colombia.

Monzón, Susana (1991). El estudio de la cerámica y su contribución a una investigación interregional. El caso de Piura. BIFEAL 20(2); pp. 589-597, Lima, Perú.

Moya Espinoza, Reynaldo (1994). Breve Historia de Piura. La Conquista. Instituto Cambio y Desarrollo, CYDES, Concejo Provincial de Piura, Perú.

Paz Velásquez, Juan (1986). Piura en la conquista. Vols. 1-2-3. Industria Gráfica Ubillús, Piura, Perú.
Pease G.Y, Franklin (1992). Perú. Hombre e Historia entre el siglo XVI y el XVIII. EDUBANCO, Lima, Perú.

Petersen, George (1962). "Desembarco y Primeras Operaciones Militares de Francisco Pizarro en Tierras Peruanas". En: Actas y Trabajos del II Congreso Nacional de Historia del Perú 4-9 de agosto 1958, Vol II. Lima. pp. 359-383.

Ramírez, Susan E. (1985). La élite terrateniente de la costa norte peruana: una historia económica y social de Lambayeque en la época colonial, 1700-1821; pp. 251-279. En: Enrique Florescano. Orígenes y desarrollo de la burguesía en América Latina, 1700-1995. México: Edic. Nueva Imagen.

Ramírez, Susan E. (2002). Don Clemente Anto, procurador del común del pueblo de Lambayeque; pp. 831840. En: En: El hombre y los Andes: homenaje a Franklin Pease G.Y. / Javier Flores Espinoza y Rafael Varón Gabai, eds., Vol. 2, Lima: PUCP. Fondo Editorial.

Ramón Valarezo, Galo (2004). La región en las utopías lojanas. En: Hacia la elaboración de una imagen compartida de la región sur; pp. 79-86. Memorias del Seminario Taller. Ediciones Abya-Yala, Quito, Ecuador y Universidad Nacional de Loja, Ecuador.

Ramos, Demetrio (1972). Benalcázar y la primera Piura. UDEP, Colección Algarrobo, $\mathrm{N}^{\circ}$ 6, Perú.

Ramos Seminario, Isabel y Guillermo Garrido-Lecca Frías (1996). San Miguel de Piura: vínculos de sangre, 1650 a 1940. Ultrapage, Piura, Perú.

Revesz, Bruno, Susana Aldana, Laura Hurtado y Jorge Requena (1997). Piura: región y sociedad. Derrotero bibliográfico para el desarrollo. Piura-Cusco: Cipca, Cera, Bartolomé de las Casas.

Revesz, Bruno (1992). "Catacaos: una comunidad en la modernidad". Debate Agrario, No 14: 74-105. Junio-setiembre.

Revesz, Bruno (2013). Miradas cruzadas. Políticas públicas $y$ desarrollo regional en el Perú. Lima: CIPCA-IEP.

Rodríguez, Aurelio y Carlos Campos (2010). «Resultados preliminares de las excavaciones arqueológicas en San San Miguel de Piura, durante la temporada 20052006"; pp. 84-96. En: San Miguel de Piura, primera fundación española en el Perú. Informe de bases y avance del Plan Director del sitio arqueológico de Piura la Vieja, La Matanza (Piura, Perú). Madrid: Mairea Libros.

Rosas Navarro, Ruth (2013). Mentalidad y discurso religioso en la transición hacia la independencia en el norte del Virreinato peruano. El Partido de Piura. Máster 
Iberoamericano en Historia Comparada. Universidad de Huelva. España.

Rosas Navarro, Ruth (2019). Religiosidad en el Partido de Piura durante el proceso de la Independencia, 1780-1821. Tesis Doctora en Historia Comparada. Patrimonio. Universidad de Huelva, España.

Rostworowski, María (1982). Testamento de don Luis de Colán: curaca en 1622; pp.507-543. En: Revista del Museo Nacional. Tomo XLVI, Lima. Perú. 1961. Curacas y sucesiones: costa norte. Edit. Minerva, Lima, Perú.

Schlüpmann, Jakob (1993). La structure agraire et le développement d'une société régionale au nord du Pérou. Piura, 1588-1854. París: Université de Paris VII Denis Diderot, 2 ts.

Sir Jiménez, Violeta Stephany (2019). Influencia de la globalización en la pérdida de la cultura arquitectónica piurana. Análisis a nivel distrital Piura, 2016. Tesis de Licenciatura de Arquitectura, Universidad Nacional de Piura, Piura, Perú.

Sir Francis Drake, Thomas Cavendish, William DAmpier (1910). Famous english naval adventurers and circumnavigators of the Globe. Promoters of Great Britain's Supremacy on the Sea. Their Lives and Voyages. History of the Bucaniers. The Werner Company, New York and Akron, Ohio, USA.

Vargas, Cristina (coord.) (2017). El Niño costero y las instituciones culturales. Informe sobre las afectaciones y recomendaciones para su prevención. UDEP, Perú. https://drive.google.com/file/d/0B6AM_ethaEyRam9 tZENYcUdDOVk/view Consultado 15.12.2018

Vega, Juan José (1993). Pizarro en Piura. Piura: CYDES, Concejo Provincial de Piura.

Vela Cossío, Fernando (2014). Retos y oportunidades de la Arqueología histórica en el Perú. El caso de la ciudad de San Miguel en Piura La Vieja; pp. 25-58. En: Patrimonio, identidad y memoria. Lima: Universidad Ricardo Palma.

Vela Cossío, Fernando (2010). Informe de bases y avance de Plan Director del sitio arqueológico de Piura la Vieja, La Matanza (Piura, Perú). Madrid: Mairea Libros.
Vela Cossío, Fernando (2012). La ciudad de San Miguel en su paisaje histórico; pp. 51-83. En: revista Allpanchis, Año XLIII, Nº 80, Cusco, Perú.

Velásquez, C. (2014). Financiamiento y creación de escuelas y colegios en Piura (1827-1890): Educación en Piura en los albores de la república. Tesis de pregrado en Educación, Especialidad en Historia y Ciencias Sociales. Universidad de Piura. Facultad de Ciencias de la Educación. Piura, Perú.

Velezmoro Montes, Víctor (2004). Capítulo 1. Orígenes y primeros tiempos. Capítulo 2. La conquista Inca; pp. 1-95. En: Del Busto, José A. Historia de Piura. Departamento de Humanidades, Universidad de Piura, Perú.

Vílchez Carrasco, Carolina (2015). El camino inca de la costa en el parque nacional cerros de Amotape. Subtramo 1 del Tramo Tumbes; pp. 1-12. Ministerio de Cultura. Qhapaq Ñan. Perú. (2015). El camino costero en la planicie litoral de Tumbes. Sub tramo 3 del Tramo Tumbes; pp. 1-10. (2015). El camino Inca de la costa en Tumbes; pp. 1-13. (2015). Cabeza de Vaca en las crónicas y relatos de viajeros; pp.1-9.

Villanueva, Luis de; Fernando Vela Cossío; Alfonso Navarro y David Rivera (2004). «La ciudad de San Miguel de Piura, primera fundación española en el Perú»; pp. 267-294. En: Revista Española de Antropología Americana, $\mathrm{N}^{\circ} 32$, Madrid.

Universidad Politécnica de Madrid (2006). Proyecto de Investigación histórica, arqueológica, arquitectónica y urbana. San Miguel de Piura: primera fundación española en el Perú (1534). Fase 1: evaluación potencial del yacimiento arqueológico.

http://composicion.aq.upm.es/Investigacion/ ProyectoPiuraWEB.pdf

Consultado 20.11.2020

Universidad Politécnica de Madrid (2006). San Miguel de Piura: primera fundación española en el Perú. http://composicion.aq.upm.es/Investigacion/ ProyectoPiuraWEB2006.pdf

Consultado 20.11.2020 


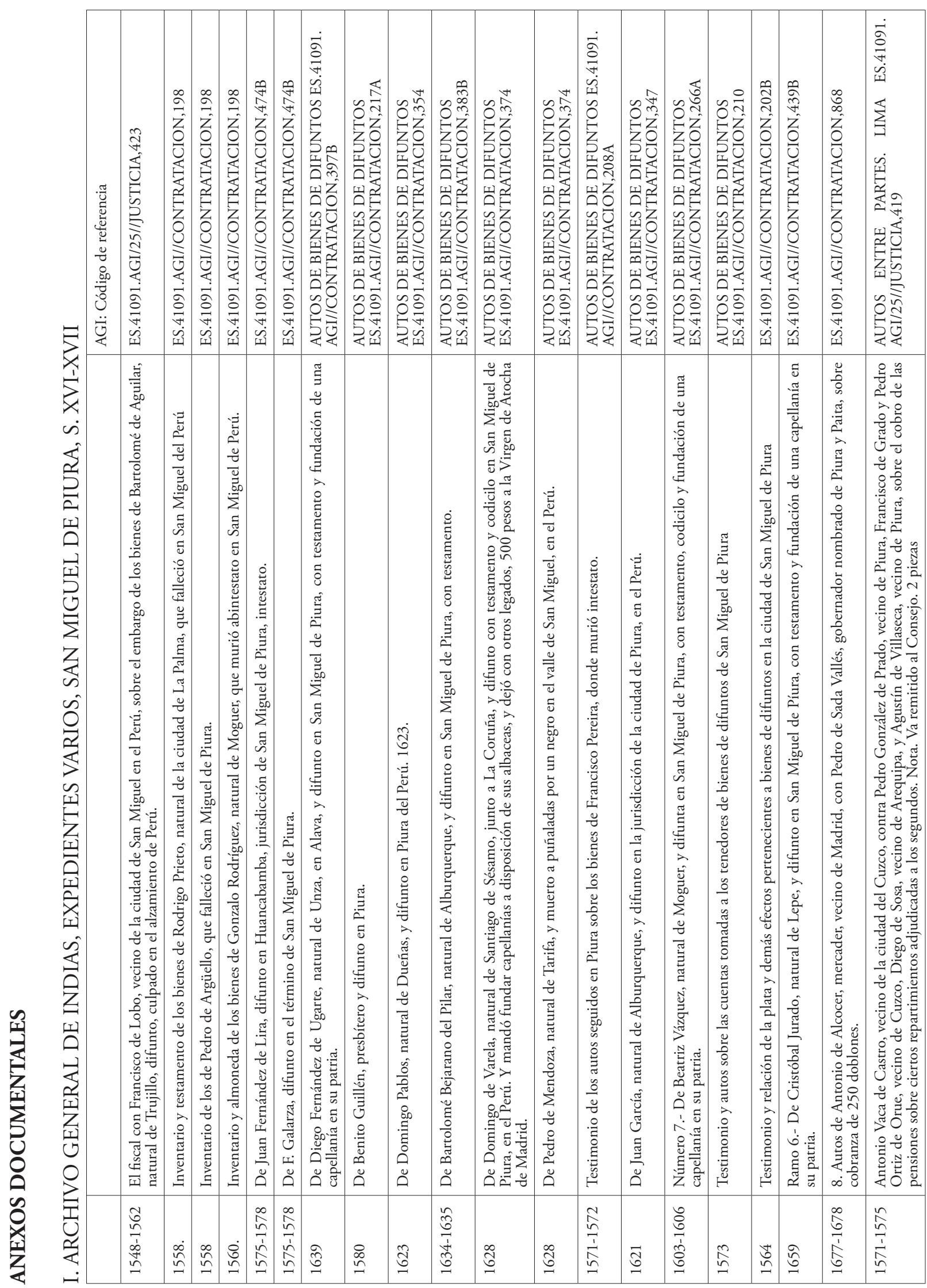




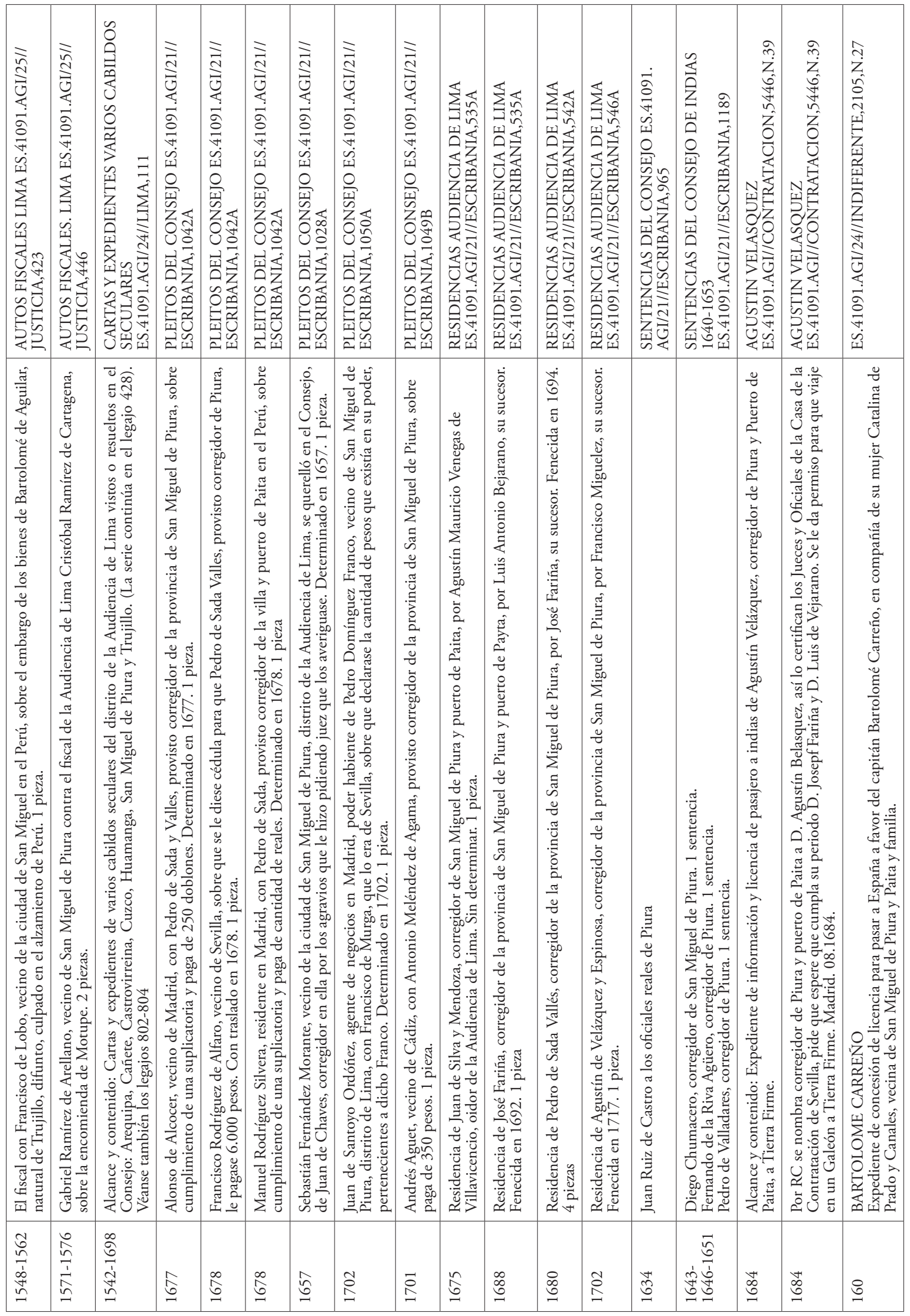




\section{ANEXO 2. Cesión de las tierras de Tangarará de esta banda, D. Francisco de Sojo a Simón de los Reyes $^{23}$}

Yo el infrascripto escribano cumpliendo con lo pedido y mandado en el escrito y decreto de la foja antecedentes procedo a tomar razón del documento a que la refiere cuyo tenor es el siguiente:

Sepan cuantos esta publica escritura vieren como nos el capitán Francisco de Sojo, regidor Fiel Ejecutor de esta ciudad de San Miguel de Piura y su jurisdicción y doña Catalina Cornejo de Cantoral, su mujer, y con licencia y expreso consentimiento decimos que los dos tenemos en termino de esta ciudad siete leguas de ella en el rio que llaman de La Chira, una hacienda nombrada San Francisco de Tangarará, que yo el dicho capitán Francisco de Sojo funda y linda desde uno de los corrales que está en el sitio que llaman Guan y Guaca de la Chira por otro nombre La Capullana corriendo el rio arriba hasta pasada la Quebrada Grande de Poechos donde está el mojón, y corriendo por la dicha Quebrada arriba hasta la Quebrada de la Solanilla que entra en la Quebrada Grande de la Solana con todos sus jagueyes Quebrada de Saman, y todo lo demás que le pertenece a dicha Hacienda en la cual tenemos en el presente tres mil cabezas de ganado cabrío y ovejuno chicos y grandes y unas piezas de esclavos de los nombres siguientes: una negra llamada María Saraza con dos hijos, el uno llamado Mateo y el otro Mauricio, criollos de esta ciudad que serán de 18 ańos. Un mulato llamado Gaspar de Arcila de 45 años de edad. Otro llamado Antonio de 40 años. Un negro llamado Juan Solano de edad de 50 años. Otro llamado Manuel Mandinga de 50 ańos. Otro llamado Bernardo Lucumí de edad de 50 años. Otro Domingo de casta Congo de edad 30 años. Otro llamado Juan de casta Arara de edad de 40 años. Otro llamado Felipe Rondón de edad 20 ańos, todos ganaderos y chacareros para el servicio de la dicha Estancia y Hacienda, para la cual están señalados y repartidos por provisión del Real Gobierno cinco indios mitayos enteros, y uno de quiebra del pueblo de Catacaos, los dos de ellos de la Parcialidad

23 ARP. 1838. JPI. CC. Caja 39, Expediente 773. Autos de la causa mortuoria del finado D. Manuel Benites fechado en 26.06.1838. Escribano Público D. Manuel Jose de la Vega. Expediente en la que se procesa la venta y remate de una casa en la ciudad de SM de Piura y de un potrero ubicado colindante a la hacienda de Tangarará. de Mechato, uno de la Parcialidad de Narigualá, otro de la de Menón, otro de La Chira, y otro que es el de la quiebra de la Parcialidad de la Muñuela. Y porque somos casado y velado según orden de la Santa Madre Iglesia a doña María Leonarda de Sojo nuestra hija con el capitán Matías Gonzales de Sangines y a doña Águeda de Sojo nuestra hija con D. Baltasar de Y(?) y Socovio vecinos de esta ciudad, que cada una le hemos dado una dote y casamiento a 15 mil pesos de a ocho reales como parecerá por las escrituras otorgadas ante el presente escribano, la una el año pasado de 1685 y la otra el de 1688 , y porque no se hallaran sin medios ni plata con que poder acomodar a $\mathrm{D}$. Juan de Sojo nuestro hijo mayor, y hallarse en edad de más de 27 años y no tener una posesión para buscar con que pasar esta vida, una firmes y conformes hemos venido en darles la dicha Estancia y hacienda de Tangarará con todos sus ganados, pastos y sitios, jagueyes y abrevaderos, casas y corrales, y todo lo demás que le toca y pertenece, los servicios de los mitayos y esclavos referidos, y todo lo que hay en dicha hacienda, reservando como reservamos para nosotros cuatro manadas de matanza que están hechas, y la han de matar en el ańo que viene de 1691 y hemos de pagar los pastores que las guardan, que engordan hasta el día que se acaba de matar, y se reservan como asimismo reservamos las tierras de la dicha Estancia de Tangarará de esta banda del rio; porque estas han de ser para Simón de los Reyes cuarterón libre, con más 300 cabezas de ganado que el dicho don Juan de Sojo nuestro hijo ha de tener obligación de entregarle a dicho Simón de los Reyes, en teniendo 20 años de edad y ponérselos en las dichas tierras de esta banda, desde ahora para siempre jamás cedemos y traspasamos en el dicho Don Juan de Sojo nuestro hijo la dicha Estancia y Hacienda de Tangarará, con todos sus ganados, pastos, sitios, jagueyes y abrevaderos, casas, corrales, servicios de mitayos, esclavos y todo lo demás que hay en dicha Hacienda según y como va referido y con las reservas expresadas, libres de censo, capellanía, obligación alguna que no la tiene ni se le ha de poder echar y cargar en todo el tiempo de nuestra vida sino que ha de estar libre y sin obligación alguna en precio y cuantía de 25 mil pesos de a 8 reales que nos ha costado en los cuales ha de haber y recibir el dicho don Juan de Sojo nuestro hijo la dicha Estancia y Hacienda, y todo lo demás referido por cuenta de su legítima paterno y materno, con la 
calidad y condición que la cantidad que le tocara de menos al tiempo de la división y partición nuestros bienes la ha de traer a colación partición y división entre los demás que fueren nuestros herederos, quedándose siempre el dicho don Juan de Sojo con la dicha Estancia y Hacienda y demás referido porque es nuestra voluntad que como hijo mayor quede con ella. Y con calidad y condición que todos los días de nuestra vida nos ha de dar y entregar mil pesos de a ocho reales en cada un año con dos pagas de seis en seis meses a quinientos en cada una así en el tiempo que yo el dicho capitán Francisco de Sojo viviere, como en el que viviera yo la dicha doña Catalina Cornejo de Cantoral sin que sea visto ni entendido que por la muerte de uno haya de haber rebaja de los dichos mil pesos, porque al que quedara se le han de dar enteramente porque son para ayuda de los gastos de nuestra casa y familia, y por esta cantidad ha de ser ejecutado siempre que no la diere y pagara hasta que lo haga.

Y con calidad y condición que si con los dichos mil pesos no tuviéramos suficientemente con que poder sustentarnos y mantenernos nos ha de dar el dicho don Juan de Sojo nuestro hijo lo que le pidiéramos por cuenta de los 25 mil pesos en que le hacemos esta cesión y traspaso, y lo que así nos diere constando de nuestros recibos se le ha de recibir y pasar en cuenta de la cantidad que hubiese de volver y traer a colación y partición, lo cual se entiende de lo que diere demás de los dichos mil pesos, porque estos nos lo ha de dar sin cargo de recibo por la demasía que hay de los 15 mil pesos que hemos dados a cada una de las dichas sus hermanas a los 24 mil pesos en que recibiera la dicha Estancia y Hacienda.

Y con calidad que las manadas de matanza y carnes que han de pasar libremente deteniéndose en los pastos de esta banda y de la misma suerte en los demás ganado que fuere a la dicha Hacienda. Y con calidad que todas las veces que por el dicho Simón de los Reyes o por otra cualquiera persona que subceda en las dichas tierras y pastos de esta banda las hubiese de vender, ha de ser preferido por el tanto que otro diere, el que fuere dueño de la dicha Estancia de Tangarara, el cual ha de poder tener siempre balsa en que poder pasar de la una banda a la otra, sin que por ningún caso se le pueda embarazar, porque con estas calidades le damos las dichas tierras y pastos de esta banda al dicho Simón de los Reyes, y son los linderos desde el sitio de Yutusina rio abajo hasta la quebrada de Macacará con sus salidas.

Y con condición que el de primero de enero del año que viene de 1691 años ha de entrar poseyendo el dicho don Juan de Sojo nuestro hijo la dicha Estancia y Hacienda y todo lo demás referido que la damos y traspasamos. Y con las dichas calidades y condiciones otorgamos que damos al dicho don Juan de Sojo nuestro hijo la dicha Estancia y Hacienda y todo lo demás referido por las causas y razones susodichas y porque así es nuestra determinada voluntad. Y nos desistimos y apartamos del derecho y acción de propiedad, posesión, señorío, titulo, voz, recurso que tenemos a la dicha hacienda y estancia y demás referido, y cumpliendo como ha de cumplir el dicho nuestro hijo con las calidades y condiciones expresada se lo renunciamos y traspasamos todo en el susodicho para que desde el día primero de enero para siempre jamás sea dueńo de todo lo que le damos y cedemos, y le damos poder para que tome la posesión de todo ello, y en señal de ella le entregamos los títulos de la dicha estancia y hacienda, tierras y pastos y provisiones de data en mitayos y venta de esclavos y prometemos de haber por firme todo lo contenido en esta escritura y de no ir contra ella en ningún tiempo, ni la revocaremos por testamento, ni por codicilo ni en otra manera tacita ni expresamente, y si la revocaremos no valga la tal revocación, y por el mismo caso quede aprobada y revalidada, y damos por suplidas cualesquier faltas y defectos que de hecho o de derecho substancial o solemnidad en esta escritura pueda haber, todo lo cual sea visto y entendido en darle más fuerza y valor.

Y hallándome presente yo el dicho don Juan de Sojo Cornejo de Cantoral, al contenido en esta escritura digo que la he oído y entendido, y que la acepto según como en ella contiene y que recibo de los dichos capitán Francisco de Sojo y dońa Catalina Cornejo mis padres la dicha hacienda y Estancia de Tangarará con sus pastos, sitios, jaguayes y abrevaderos, casas y corrales y tres mil cabezas de ganado chico y grande y las once piezas de esclavos y servicios de mitayos referidos, y todo lo demás que hay y pertenece a la dicha Hacienda en los 24 mil pesos de a ocho reales y por cuenta de la legitima paterna y materna, y mi obligación a cumplir todas las calidades y condiciones contenida en esta escritura, y a pagar a los dichos mis padres los un mil pesos de a ocho reales en cada un ańo, y en dos pagas, 500 pesos cada seis meses que 
han de correr y contarse desde el dicho día primero de enero del año que viene de 691, o en otra cualquier parte que cumplido el plazo se me pidan con costas de la cobranza.

Y en caso de que los dichos mis padres no tuvieran lo suficiente con los dichos mil pesos en cad un ańo para sustento y demás gastos de su casa y familia me obligo asimismo a darles la cantidad que me pidieran por cuenta de la que yo hubiera de devolver y traer a colación y partición que hubiere sido demás de los 15 mil pesos que han recibido cada una de las dichas mis hermanas hasta los 24 mil pesos en que recibo de la dicha Estancia y Hacienda, y lo demás referido.

Y todos tres los dichos capitán Francisco de Sojo, dońa Catalina Cornejo Cantoral y don Juan de Sojo, por lo que a cada uno toco al cumplimiento de esta escritura obligamos nos los dichos capitán Francisco de Sojo y don Juan de Sojo nuestras personas y bienes, y yo la dicha dońa Catalina Cornejo los míos y todos los habidos y por haber, y es calidad y condición que si yo el dicho don Juan de Sojo vendiere la dicha hacienda y estancia de Tangarara, por el tanto que otro le diere ha de ser preferido cualesquiera de los herederos de por los dichos capitán Francisco de Sojo y doña Catalina Cornejo de Cantoral, y damos poder a las justicias y jueces de su Majestad de cualquier partes que sean a cuya jurisdicción y fuero no sometemos, renunciamos el nuestro propio domicilio y vecindad y la ley sitcummerit de jurisdictione ómnium yudicumi y la última pragmática de sumisiones, para que por todo rigor de derecho nos compelan y apremien a lo que el dicho es como por sentencia definitiva, de juez competente pasada en autoridad de cosa juzgada, y por nosotros consentida, y para ello renunciamos todas las demás leyes, fueros y derechos de nuestro favor con la que prohíbe la general renunciación de leyes.

E yo la dicha doña Catalina Cornejo de Cantoral renuncio las leyes del Beleyan Senatrus consultes nuevas constituciones, leyes del Toro Madrid y Partida de cuyo efecto ha sido noticiada por el presente escribano, y juro por Dios nuestro señor y una señal de la Santa Cruz de no oponerme contra esta escritura por mi dote, arras, ni bienes hereditarios parafernales ni multiplicados ni por otro derecho que me pertenezca, y que no alegase haber sido inducida ni apremiada por el dicho mi marido ni por otra persona para otorgarla, antes declaro lo hago de mi voluntad y que se convierta en utilidad mia, y que no tenga hecha ni hare protestación en contrario, y si pareciere la revoco y no pediré absolución ni relajación de este juramento a quien de derecho me lo pueda conceder, y aunque de propio motu se me conceda, no usaré de ella pena de perjura.

Que es fecha la carta en esta dicha ciudad de San Miguel de Piura a 12 días del mes de diciembre de 1690 años. Y los otorgantes a quienes yo el escribano doy fe, que conozco, lo firmaron de sus nombres siendo testigos el Gobernador Don Francisco Idiaquez, Juan Dávila y Antonio López Fernandez, vecinos de esta dicha ciudad.

Francisco de Sojo. Dońa Catalina Cornejo de Cantoral. Juan de Sojo Cantoral. Ante mi don Domingo Valencia escribano Publico y Real y de Cabildo.

E yo el dicho escribano hice sacar y saque este traslado de la escritura original que queda en mi registro, comenzando la saca en el Pliego del sello segundo que va para el año que viene de 1691 que me lo dio el tesorero Domingo de Mata quien corre con la venta del papel sellado por no haberla de dicho sello para este presente año, esta cierto y verdadero, corregido y consertado, y en fe de ello lo signo y firmo en esta ciudad de San Miguel de Piura a 15 días del mes de diciembre de 1690 años. En testimonio y verdad don Domingo Valencia escribano Publico Real y de Cabildo.

Concuerda con el documento de sesión de su contenido que corre de fojas una a fojas siete de testimonio de los autos seguidos por don Pascual de Viera contra Simón de los Reyes sobre linderos de las tierras de Yutusina en el año de 1715, el que devolví al señor coronel Don Francisco Xavier Fernandez de Paredes, a que me remito y de que certifico. Piura 25 de junio de 1838. Manuel José de la Vega, Escribano Público. 